NBER WORKING PAPER SERIES

\author{
MEETING THE MANDATE FOR BIOFUELS: \\ IMPLICATIONS FOR LAND USE, FOOD AND FUEL PRICES \\ Xiaoguang Chen \\ Haixiao Huang \\ Madhu Khanna \\ Hayri Önal \\ Working Paper 16697 \\ http://www.nber.org/papers/w16697
}

\author{
NATIONAL BUREAU OF ECONOMIC RESEARCH \\ 1050 Massachusetts Avenue \\ Cambridge, MA 02138 \\ January 2011
}

Funding from the Energy Biosciences Institute, University of California, Berkeley, the U.S. Department of Energy and NIFA, USDA is gratefully acknowledged. The views expressed herein are those of the authors and do not necessarily reflect the views of the National Bureau of Economic Research.

NBER working papers are circulated for discussion and comment purposes. They have not been peerreviewed or been subject to the review by the NBER Board of Directors that accompanies official NBER publications.

(C) 2011 by Xiaoguang Chen, Haixiao Huang, Madhu Khanna, and Hayri Önal. All rights reserved. Short sections of text, not to exceed two paragraphs, may be quoted without explicit permission provided that full credit, including $\odot$ notice, is given to the source. 
Meeting the Mandate for Biofuels: Implications for Land Use, Food and Fuel Prices

Xiaoguang Chen, Haixiao Huang, Madhu Khanna, and Hayri Önal

NBER Working Paper No. 16697

January 2011

JEL No. C6,Q4,Q5

\begin{abstract}
Biofuel production is being promoted through various policies such as mandates and tax credits. This paper uses a dynamic, spatial, multi-market equilibrium model, Biofuel and Environmental Policy Analysis Model (BEPAM), to estimate the effects of these policies on cropland allocation, food and fuel prices, and the mix of biofuels from corn and cellulosic feedstocks over the 2007-2022 period. We find that the biofuel mandate will increase corn price by $24 \%$, reduce the price of gasoline by $8 \%$ in 2022, and increase social welfare by $\$ 122 \mathrm{~B}(0.7 \%)$ relative to Business As Usual scenario. The provision of volumetric tax credits that accompany the mandate significantly changes the mix of biofuels produced in favor of cellulosic biofuels and reduces the share of corn ethanol in the cumulative volume of biofuels produced from $50 \%$ to $10 \%$. The tax credits reduce the adverse impact of the mandate alone on crop prices and decrease the price of biofuels. However, they impose a welfare cost of \$79 B compared to the mandate alone. These results are found to be sensitive to the rate of growth of crop productivity, the costs of production of bioenergy crops, and the availability of marginal land for producing bioenergy crops.
\end{abstract}

Xiaoguang Chen

Institute for Genomic Biology

University of Illinois at Urbana Champaign

1206 West Gregory Dr

Urbana, IL 61801

xchen29@illinois.edu

Haixiao Huang

Institute for Genomic Biology

University of Illinois at Urbana Champaign

1206 West Gregory Dr

Urbana, IL 61801

hxhuang@illinois.edu
Madhu Khanna

Department of Agricultural and Consumer Economics University of Illinois at Urbana Champaign

326 Mumford Hall

1301 Gregory Dr

Urbana, IL 61801

khanna1@illinois.edu

Hayri Önal

Department of Agricultural and Consumer Economics

University of Illinois at Urbana Champaign

326 Mumford Hall

1301 Gregory Dr

Urbana, IL 61801

h-onal@illinois.edu 


\section{Meeting the Mandate for Biofuels: Implications for Land Use, Food and Fuel Prices}

Concerns about energy security, high oil prices and climate change mitigation have led to increasing policy support for the production of biofuels in the U.S. In 2008, the production of U.S. corn ethanol more than tripled relative to 2001 with the production of 9 billion gallons using one-third of U.S. corn production (USDA 2010). Prices of agricultural commodities doubled between 2001 and 2008, leading to a debate about the extent to which the price increase was caused by biofuels and the competition for land induced by them (USDA/ERS 2010). A number of studies have analyzed the impact of biofuel demand on the price of crops and obtained widely varying estimates depending on the choice of price index, the baseline and the other contributing factors considered. Reviews of these studies by Pfuderer, Davies and Mitchell (2010), and Abbott, Hurt and Tyner (2008) shows that biofuels did contribute to the spike in crop prices in 2008 but with the current relatively low levels of diversion of global corn production to biofuels, they were not the key drivers of the price increase. The trade-offs between food and fuel production could, however, intensify in the future as the Renewable Fuel Standard (RFS) established by the Energy Independence and Security Act (EISA) of 2007 seeks a six-fold increase in biofuel production by 2022.

Recognition of these trade-offs and the limits to relying on corn-based ethanol to meaningfully reduce dependence on oil, has led to growing interest in developing advanced biofuels from feedstocks other than corn starch. A commercial technology to produce cellulosic biofuels is yet to be developed but efforts are underway to produce them from several different feedstocks such as crop and forest residues and perennial grasses (such as, miscanthus and switchgrass). The use of residues does not require diversion of land from food production while perennial grasses are not only likely to be more productive in their biofuel yields per unit of land 
than corn ethanol but can also be grown on marginal lands. Cellulosic biofuels are expensive compared to corn ethanol and unlikely to be viable without biofuel support policies. The RFS mandates an increasing share of biofuel production from non-corn starch feedstocks; this increases to 58\% in 2022. The Food, Conservation, Energy Act (FCEA) of 2008 also provides a variety of volumetric tax credits for blending biofuels with gasoline with higher tax credits for advanced biofuels ( $\$ 0.27$ per liter) than for corn ethanol (\$0.12 per liter) with the intent of making them competitive with corn ethanol. These tax credits lower fuel prices and to the extent that they shift the mix of biofuels towards cellulosic feedstocks relative to the mandate alone, they could also lower crop prices. The decrease in fuel prices could however lead to an increase in fuel consumption relative to the RFS alone.

This paper examines the effects of the RFS and accompanying volumetric subsidies for land use, food and fuel production and prices in the US. We analyze the extent to which these policies lead to changes in cropping patterns on the intensive margin and to an expansion of cropland acreage. We also analyze the tradeoff they pose between fuel and food production and the mix of cellulosic feedstocks that are economically viable under alternative policy scenarios.

Furthermore, we examine the welfare costs of these policies and the costs of these tax credits for domestic taxpayers. A recent report by the CBO (2010) estimates that the volumetric tax credit costs tax payers $\$ 0.47$ per liter of (gasoline energy equivalent) corn ethanol and $\$ 0.79$ per liter of (gasoline energy equivalent) cellulosic biofuels. The study assumes that these tax credits lead to a $32 \%$ increase in corn ethanol production and a $47 \%$ increase in cellulosic biofuel production, over and above that otherwise. Metcalf (2008) attributes all of the corn ethanol consumption above the mandate in 2005 to the corn ethanol tax credits and estimates that tax credits increased consumption by $25 \%$. McPhail and Babcock (2008) find a much smaller role 
for the effect of the corn ethanol tax credit in 2008/2009; they estimate that it increased domestic supply by about 3\% compared to the mandate alone. With two types of biofuels, corn ethanol and cellulosic biofuels, receiving tax credits at differential rates, determining the incremental effect of these tax credits in the future is more challenging, since they could affect not only the total volume of biofuels but could create incentives to increase one type of biofuel at the expense of another. Moreover, the cost of these tax credits should include not only the direct effect on tax payers but also the indirect effect on consumers and producers of agricultural and fuel products. These policies will differ in their impacts on food and fuel consumers and producers and are likely to benefit agricultural producers and fuel consumers while adversely affecting gasoline producers and agricultural consumers. In an open economy with trade in agricultural products and gasoline, some of these costs are passed on to foreign producers and consumers. We use the framework developed here to jointly determine the economic costs (in terms of domestic social welfare) of these tax credits as well as the extent to which they lead to incremental biofuel production above the mandated level and change the mix of biofuels. Finally, we analyze the sensitivity of the impact of the these biofuel policies on the mix of feedstocks used and on food and fuel prices to several supply-side factors, such as the costs of various feedstocks and biofuels, the growth in productivity of conventional crops and the availability of land.

We develop a dynamic, multi-market equilibrium model, Biofuel and Environmental Policy Analysis Model (BEPAM), which analyzes the markets for fuel, biofuel, food/feed crops and livestock for the period 2007-2022. We consider biofuels produced not only from corn but also from several cellulosic feedstocks and imported sugarcane ethanol while distinguishing between domestic gasoline supply and gasoline supply from the rest of the world. BEPAM treats 
each Crop Reporting District (CRD) as a decision making unit where crop yields, costs of crop and livestock production and land availability differ across CRDs. Food and fuel prices are endogenously determined annually and used to update price expectations, cropland acreage and land use choices. The rest of the paper is organized as follows. In Section II we review the existing literature and the key contributions of our research. In Section III we briefly describe the current legislations whose effects are being analyzed here. Section IV describes the simulation model. Data used for the simulation model is described in Section $V$ followed by the results and conclusions in Sections VI and VII.

\section{Previous Literature}

A number of studies have examined the implications of biofuel production and policies for food/feed prices and land use in the long run. Using the partial equilibrium FAPRI model, Elobeid et al. (2007) analyze the long run effects of crude oil price changes on demand for ethanol and corn while Elobeid and Tokgoz (2008) expand that analysis to show the extent to which the effects of expansion in corn ethanol production on food/feed prices can be mitigated by liberalizing import of biofuels from Brazil. More recently, Fabiosa et al. (2009) use the model to obtain acreage multiplier effects of corn ethanol expansion. These studies (like Tyner and Taheripour 2008) consider an exogenously given price of gasoline and assume that ethanol and gasoline are perfectly substitutable. As a result, the price of ethanol is determined by the price of gasoline (based on its energy content relative to gasoline) and there is a one-directional link between gasoline prices and corn prices, resulting in a perfectly elastic demand for corn at the break-even price at which ethanol refineries can make normal profits. These studies also assume that crop yields are constant over time. 
Ferris and Joshi (2009) use AGMOD to examine the implications of the RFS for ethanol and biodiesel production (2008-2017), assuming perfect substitutability between gasoline and ethanol and no cellulosic biofuel production. They find that the mandate could be met by potential crop yield increases and a decline in land under the Conservation Reserve Program and cropland pasture.

Unlike the models used in above studies which focus only on corn ethanol, the POLYSYS model includes various bioenergy crops and investigates land use impacts of biofuel and climate policies (Ugarte et al. 2003). Walsh et al. (2003) apply POLYSYS to examine the potential for producing bioenergy crops at various exogenously set bioenergy prices. English et al. (2008) analyze the effects of the corn ethanol mandate (assuming that cellulosic biofuels are not feasible) and show that it will lead to major increases in corn production in the Corn Belt and in fertilizer use and soil erosion over the period 2007-2016. Most recently, Ugarte et al. (2009) apply POLYSYS to analyze the implications on agricultural income, over the 2010-2025 period, of various carbon prices and carbon offset scenarios under a GHG cap and trade policy assuming the RFS exists.

The impact of climate change policies on the agricultural sector and biofuel production has been examined by McCarl and Schneider (2001) using FASOM, a multi-period, price endogenous spatial market equilibrium model, with a focus on land allocation between agricultural crops and forests. Like the above studies, FASOM also assumes that gasoline and ethanol are perfectly substitutable, but determines the price of gasoline endogenously using an upward sloping supply curve for gasoline. The model includes an autonomous time trend in crop yields and considers various bioenergy feedstocks, such as crop and forest residues, switchgrass, and short-rotation woody crops. FASOM is used by EPA to simulate the impacts of 
implementing the RFS relative to 2007 Annual Energy Outlook (EIA 2007) reference case (EIA 2010). Results show that the RFS would increase corn and soybeans prices in 2022 by $8 \%$ and $10 \%$, respectively, and decrease gasoline price by 0.006 cents per liter relative to the AEO 2007 Reference Case. Total social welfare in 2022 is \$13-26 B higher than the reference level.

In addition to these partial equilibrium studies, the general equilibrium GTAP model has been used to examine the global land use effect of corn ethanol mandate in the U.S. and a biofuel blend mandate in European Union in 2015, assuming no cellulosic biofuel production (Hertel, Tyner and Birur 2010) and imperfect substitutability between gasoline and ethanol (Birur, Hertel and Tyner 2008). Reilly et al. (2009) use the general equilibrium EPPA model to examine the implications of greenhouse gas reduction targets over the 2015-2100 period for second generation biomass production and changes in land use. Their simulations suggest that it is possible for significant biofuel production to be integrated with agricultural production in the long run without having dramatic effects on food and crop prices.

The model developed in this paper differs from the existing models in the literature in several aspects. First, we allow imperfect substitutability between gasoline and ethanol. Bottlenecks within the ethanol distribution infrastructure, the existing stock of vehicles and constraints on the rate of turnover in vehicle fleet limit the substitutability between biofuels and gasoline. Empirical evidence shows that biofuel prices are not simply demand driven (based on energy equivalent gasoline prices and perfect substitutability); instead they have been observed to be correlated with their costs of production as well. ${ }^{1}$ It is difficult to estimate and predict the substitution possibility between these fuels in the near future as it is directly related to the vehicle fleet structure. Therefore, we examine the implications of a range of substitutability between gasoline and ethanol and implicitly derive the demand for the two fuels. Hayes et al. (2009) show 
that incorporating imperfect substitutability between ethanol and gasoline in the FAPRI model results in a substantially smaller impact of a change in crude oil prices on demand for ethanol and land use than in Tokgoz et al. (2007). Additionally, we assume two upward sloping supply functions of gasoline and allow biofuel production to have a feedback effect on gasoline prices and thus on the demand for biofuels (as in Hayes et al. 2009). The U.S. accounts for $23 \%$ of world petroleum consumption, and about $57 \%$ of the consumption is imported from the rest of the world (EIA 2010); thus the change in U.S. oil demand can significantly affect world oil prices. To capture the effect of biofuel policy on gasoline prices, this study considers gasoline supply from domestic producers and the rest of world.

Crop yield changes over time influence the land needed to meet food and fuel needs to meet biofuel mandates. Dumortier et al. (2009) show that introduction of even a $1 \%$ increasing trend in corn yield in the FAPRI model can substantially reduce the corn acreage in response to changes in gasoline and biofuel prices We allow for changes in crop yields over time from two sources, an endogenous price effect and an autonomous technology effect, using econometrically estimated elasticities and time trend .

Existing models such as FASOM rely on historically observed crop mixes to constrain the outcomes of linear programming models and generate results which are consistent with farmers' planting history. To accommodate new bioenergy crops and unprecedented changes in crop prices in the future FASOM allow crop acreage to deviate 10\% from observed historical mixes. In BEPAM, we use the estimated own and cross price crop elasticities to limit the flexibility of crop acreage changes, instead of an arbitrary level of flexibility. 


\section{Policy Background}

The EISA established the RFS in 2007 to provide an assurance of demand for biofuels beyond levels that might otherwise be supported by the market. It establishes a goal of 136 billion liters of biofuel production in 2022 that includes four separate categories of renewable fuels, each with a separate volume mandate. Of the $136 \mathrm{~B}$ liters of the renewable fuel, the RFS requires that at least 80 B liters should be advanced biofuels. Advanced biofuel specifically excludes ethanol derived from corn starch. It includes ethanol made from cellulose, hemicelluloses, lignin, sugar or any starch other than corn starch as long as it achieves a GHG reduction of 50\% compared to gasoline and is obtained from 'renewable biomass'. Renewable biomass limits the crops and crop residues used to produce renewable fuel to those grown on land cleared or cultivated at any time prior to enactment of EISA in December 2007. Crops used to produce renewable fuels that can meet the mandate must be harvested from agricultural land cleared or cultivated prior to December 2007. Land enrolled in the Conservation Reserve Program (CRP) is not allowed to be converted for the production of miscanthus and swithchgrass (EIA 2010).

Of the 80 B liters of the advanced biofuels, at least 60 B liters should be cellulosic biofuels derived from any cellulose, hemicelluloses or lignin and achieving a lifecycle GHG emission displacement of $60 \%$ compared to gasoline while the rest could be sugarcane ethanol from Brazil. Conventional biofuels produced from corn starch are capped at 56 B liters in 2022. Cumulative production of biofuels over the 2007-2022 period mandated by the RFS requires 1220 B liters of renewable fuel and at least 420 B liters of advanced biofuels while the amount of conventional biofuels cannot exceed 800 B liters during this period. 
The Food, Conservation, and Energy Act (FCEA) of 2008 provides tax credits for blending biofuels with gasoline. The tax credits for corn ethanol peaked at $\$ 0.16$ per liter in 1984, fell to $\$ 0.14$ per liter in 1990, $\$ 0.13$ per liter between 1998 and 2005 and is authorized at $\$ 0.12$ cents per liter till December $2010^{2}$. The tax credit for cellulosic biofuels is $\$ 0.27$ per liter and authorized till January 1, 2013. It also requires that cellulosic biofuels should be produced and consumed in the U.S.

In addition to biofuel mandates and volumetric tax credits, the U.S. imposes trade barriers to restrict the imports of sugarcane ethanol from Brazil. The biofuel trade policy includes a 2.5\% ad valorem tariff and a per unit tariff of \$0.14 per liter (authorized until January 2011). A key motivation for the establishment of the tariff is to offset a tax incentive for ethanol-blended gasoline. An exception to the tariff is the agreement of the Caribbean Basin Initiative (CBI) initiated by the 1983 Caribbean Basin Economic Recovery Act (CBERA). Under this agreement, ethanol produced from at least $50 \%$ agricultural feedstocks grown in CBI countries is admitted into the U.S. free of duty. If the local feedstock content is lower than the requirement, a tariff rate quota (TRQ) will be applied to the quantity of duty-free ethanol. Nevertheless, duty-free ethanol from CBI countries is restricted to no more than 0.2 B liters or 7\% of the U.S. ethanol consumption. To take advantage of this tariff-free policy, hydrous ethanol produced in other counties, like Brazil or European countries, can be imported to a CBI country and exported to the U.S. after dehydration. In 2007, total imports account for roughly $6 \%$ of U.S. consumption (25.7 B liters), with about $40 \%$ of the import from Brazil and approximately $60 \%$ routed through CBI countries to avoid the import tariff. However, CBI countries have never reached the ceiling on their ethanol quota, partly due to insufficient capacity. Our analysis here assumes existing tariff policy remain in effect till 2022. 


\section{The Model}

\section{IV.1. General Description}

We develop a multi-market, multi-period, price-endogenous, nonlinear mathematical programming model which simulates the U.S. agricultural and fuel sectors and formation of market equilibrium in the commodity markets including trade with the rest of the world. We refer to this model as the Biofuel and Environmental Policy Analysis Model (BEPAM). BEPAM is a dynamic, multi-market equilibrium model, which analyzes the markets for fuel, biofuel, food/feed crops and livestock for an extendable future period (currently set for 20072022) in the U.S. This model determines several endogenous variables simultaneously, including vehicle kilometers travelled (VKT), fuel and biofuel consumption, domestic production and imports of oil and imports of sugarcane ethanol, mix of biofuels and the allocation of land among different food and fuel crops and livestock. This is done by maximizing the sum of consumers' and producers' surpluses in the fuel and agricultural sectors subject to various material balances and technological constraints underlying commodity production and consumption within a dynamic framework (McCarl and Spreen 1980; Takayama and Judge 1971). This model is designed specifically to analyze the implications of biofuel and climate policies on land use patterns, commodity markets, and the environment.

The agricultural sector in BEPAM includes several conventional crops, livestock and bioenergy crops (crop residues from corn and wheat and perennial grasses, miscanthus and switchgrass) and distinguishes between biofuels produced from corn, sugarcane and cellulosic feedstocks. Crops can be produced using alternative tillage and rotation practices. The model incorporates spatial heterogeneity in crop and livestock production activity, where crop production costs, yields and resource endowments are specified differently for each region and 
each crop assuming linear (Leontief) production functions. As the spatial decision unit, the model uses the CRDs in each state by assuming an aggregate representative producer who makes planting decisions to maximize the total net returns under the resource availability and production technologies (yields, costs, crop rotation possibilities, etc.) specified for that CRD. The model covers CRDs in 41 of the contiguous U.S. states in five major regions. ${ }^{3}$

The model uses ‘historical' and 'synthetic crop mixes’ when modeling farms' planting decisions to avoid extreme specialization in regional land use and crop production. The use of historical crop mixes ensures that the model output is consistent with the historically observed planting behaviors (McCarl and Spreen 1980; Önal and McCarl 1991). This approach has been used in some existing models also, such as FASOM, to constrain feasible solutions of programming models and generate results which are consistent with farmers’ planting history. To accommodate planting new bioenergy crops and unprecedented changes in crop prices in the future FASOM allows crop acreage to deviate $10 \%$ from the observed historical mixes. In our model we use synthetic (hypothetical) mixes to offer increased planting flexibility beyond the observed levels and allow land uses that might occur in response to the projected expansion in the biofuels industry and related increases in corn and cellulosic biomass production. Each synthetic mix represents a potential crop pattern generated by using the estimated own and cross price crop acreage elasticities and considering a set of price vectors where crop prices are varied systematically. These elasticities are estimated econometrically using historical, county-specific data on individual crop acreages for the period 1970-2007 as described in Huang and Khanna (2010). Crop yields are assumed to grow over time at an exogenously given trend rate and to be responsive to crop prices. 
The model includes five types of land (cropland, idle cropland, cropland pasture, pasture land and forestland pasture) for each CRD. We obtain CRD-specific planted acres for 15 row crops for the period 1977 to 2007 from USDA/NASS (2009) and use this to construct the historical and synthetic mixes of row crops. Cropland availability in each CRD is assumed to change in response to crop prices. The responsiveness of total cropland to crop prices as well as the own and cross-price acreage elasticities for individual crops is obtained from Huang and Khanna (2010). Data on idle cropland, cropland pasture, pasture and forestland pasture for each CRD are also obtained from USDA/NASS (2009). Idle cropland includes land use category for cropland in rotations for soil improvement, and cropland on which no crops were planted for various physical and economic reasons. The estimates of idle land include land enrolled in the CRP which could be an additional source of land available for energy crops. Land in this program is farmland that is retired from crop production and converted to trees, grass, and areas for wildlife cover. We exclude land enrolled in CRP from our simulation model. Cropland pasture is considered as a long-term crop rotation between crops and pasture at varying intervals.

Pasture land consists of land with shrub, brush, all tame and native grasses, legumes and other forage while forestland pasture is stocked by trees of any size and includes a certain percentage of tree cover. Pasture land and forestland pasture are primarily for grazing uses. We keep the level of permanent pastureland and forestland pasture fixed at 2007 levels but allow idle land and cropland pasture to move into cropland and back into an idle state. It can also be used for perennial bioenergy crop production. A change in the composite crop price index triggers a change at the extensive margin and leads to a shift in land from idle cropland and cropland pasture to land available for crop production the following year. The responsiveness of aggregate cropland supply to a lagged composite price index is econometrically estimated and the 
implications of expanding crop production to idle land and cropland acreage for average yields of conventional crops in each CRD are described in Huang and Khanna (2010). The remaining idle land/pasture land can be used for bioenergy crops. While yields of bioenergy crops are assumed to be the same on marginal land as on regular cropland there is a conversion cost to the use of idle land/cropland pasture for bioenergy crop production. In the absence of an empirically based estimate of the ease of conversion of marginal land for perennial grass production we assume a CRD-specific conversion cost equal to the returns the land would obtain from producing the least profitable annual crop in the CRD. This ensures consistency with the underlying assumption of equilibrium in the land market, in which all land with non-negative profits from annual crop production is utilized for annual crop production. As annual crop prices increase, the cost of conversion increases; the "supply curve" for idle marginal land is, therefore, upward sloping. We impose a limit of $25 \%$ on the amount of land in a CRD that can be converted to perennial grasses due to concerns about the impact of monocultures of perennial grasses on biodiversity or sub-surface water flows. We examine the sensitivity of model results to this assumption by lowering this limit to $10 \%$.

The perennial nature of the energy crops included in the model requires a multi-year consideration when determining producers' land allocation decisions in any given year. For this, we use a rolling horizon approach where for each year of the period 2007-2022 the model determines production decisions and the corresponding dynamic market equilibrium for a planning period of 10 years starting with the year under consideration. After each run, the first year production decisions and the associated market equilibrium are used to update some of the model parameters (such as the composite crop price index, land supplies in each region and crop 
yields per acre for major crops), based on previously generated endogenous prices, and the model is run again for another 10-year period starting with the subsequent year.

The behavior of agricultural consumers' behavior is characterized by linear demand functions which are specified for individual commodities, including crop and livestock products, In the crop and livestock markets, primary crop and livestock commodities are consumed either domestically or traded with the rest of the world (exported or imported), processed, or directly fed to various animal categories. Export demands and import supplies are incorporated by using linear demand/supply functions. The commodity demand functions and export demand functions for tradable row crops and processed commodities are shifted upward over time at exogenously specified rates. The crop and livestock sectors are linked to each other through the supply and use of feed items and also through the competition for land (because the grazing land needed by the livestock sector has alternative uses in crop production).

The biofuel sector distinguishes biofuels produced from corn, sugarcane ethanol and cellulosic feedstock with all biofuels being perfect substitutes for each other. Biofuel from sugarcane is imported from Brazil and CBI countries subject to policies described above. Gasoline is produced domestically as well as imported from the rest of the world. The demand for gasoline and biofuels is derived from the demand for VKT. We assume a linear demand for VKT as a function of the cost per kilometer and that VKT is produced using a blend of gasoline and biofuels. At the individual consumer level (with a conventional vehicle), the two fuels are currently perfectly substitutable in energy equivalent units up to a $10 \%$ blend. For an individual consumer with a flex fuel car the two fuels are substitutable up to an $85 \%$ blend. At the aggregate level, we consider a representative consumer that owns a vehicle fleet that consists of a mix of the two types of vehicles; in 2007, only 2.9\% of vehicles in 2007 were flex-fuel vehicles 
(EIA 2010). The ability to substitute gasoline for biofuels at the aggregate level is, therefore, limited by the mix of vehicles. It is also limited by the available ethanol distribution network and infrastructure for retail ethanol sales. We, therefore, consider gasoline and biofuel to be imperfectly substitutable at the aggregate level and use a constant elasticity of substitution function to model the aggregate blend of fuel produced. The VKT demand function and CES production function are calibrated for the base year assuming a specific value for the elasticity of substitution between gasoline and ethanol and observed base year prices and quantities of these fuels and VKT. We examine the implications of varying the extent of substitutability on the consumption of the two types of fuels and on the agricultural and fuel sectors. The demand for VKT is shifted upwards over time and the VKT consumed is determined by the marginal cost of kilometers which in turn depends on the marginal costs of gasoline and biofuels. The shares of various fuels are determined endogenously based on fuel prices.

In the presence of the RFS, the quantity mandate imposes a fixed cost of biofuel on blenders. The average cost of the blended fuel (gasoline and ethanol) will fall as the level of gasoline consumption increases, but the average cost will be greater than marginal costs for low levels of gasoline consumption. Thus, at low levels of fuel consumption blenders can be expected to price fuel based on its average cost (if average cost is greater than the marginal cost) in order to avoid negative profits. In this case VKT will be determined by the average cost of a kilometer rather than its marginal cost. If gasoline consumption is high enough (or if biofuel consumption is small) it could be profitable to use marginal cost pricing of the blended fuel. The model selects the appropriate rule for pricing the blended fuel depending on whether average cost of VKT is greater or smaller than its marginal cost.

The endogenous variables determined by the model include: (1) commodity prices; (2) 
production, consumption, export and import quantities of crop and livestock commodities; (3) land allocations and choice of practices for producing row crops and perennial crops (namely, rotation, tillage and irrigation options) for each year of the 2017-2022 planning horizon and for each CRD and (4) the annual mix of feedstocks for biofuel production, domestic production and imports of gasoline and consumption of VKT.

\section{IV.2. Algebraic Presentation}

We describe the algebraic form of the numerical model using lower case symbols to denote the exogenous parameters and upper case symbols to represent endogenously determined variables. The objective function is the sum of discounted consumers' and producers' surpluses obtained from production, consumption and trade of the crop and livestock products plus the surplus generated in the fuels sector over the 16-year planning horizon 2007-2022 and the terminal values of standing perennial grasses in 2022. The algebraic expression is given explicitly in (1):

$$
\begin{aligned}
& \operatorname{Max}: \sum_{0}^{T} e^{-r t}\left\{\sum_{z} \int_{0}^{D E M_{t, z}} f^{z}(.) d(.)+\sum_{z} \int_{0}^{E X P_{t, z}} f^{z}(.) d(.)-\sum_{z} \int_{0}^{I M P_{t, z}} f^{z}(.) d(.)+\int_{0}^{M I L_{t}} f^{z}(.) d(.)\right. \\
& -\sum_{r, q} r c_{r, q} A C R_{t, r, q}-\sum_{r, p} p c_{r, p} A C R_{t, r, p}-\sum_{r, q} r s_{r, q} A C R_{t, r, q}-\sum_{r, p} c c_{r} \Delta A C R_{t, r, p} \\
& -\sum_{k} l c_{k} L I V_{t, k}-\sum_{i} s c_{i} P R O_{t, i} \\
& \left.-\int_{0}^{G A S_{t}} f^{g}(.) d(.)-e c_{c} E T H_{t, c}-e c_{b} E T H_{t, b}\right\} \\
& +e^{-r T} \sum_{r, p}\left(v_{r, p}-w_{r}\right) A C R_{T, r, p}
\end{aligned}
$$

The first integral term in line of (1) represents the areas under the domestic demand functions from which consumers' surplus is derived. Each integral is associated with a crop, livestock, or processed commodity for which a domestic market demand is considered 
( $D E M_{t, z}$ denotes the endogenous domestic demand variable in year $\left.t ; z=\{i, j, k\}\right\}$ denotes the index set for crop commodities (i), processed products from crops ( $j$ ), and livestock commodities $(k) ; f^{z}($.$) denotes the inverse demand function for the commodity involved; and d($.$) denotes the$ integration variable). The next two integral terms account for the areas under the inverse demand functions for exports, $E X P_{t, z}$, and the areas under the import supply functions $I M P_{t, z}$ (such as sugar and sugarcane ethanol). The last integral term represents the area under the inverse demand function for kilometers traveled (denoted by $K I L_{t}$ ). The demand functions for crop products, livestock products and kilometers traveled are all characterized by linear demand functions in the current version, but other functional forms, such as constant elasticity demand functions, can be incorporated without difficulty.

The second line in (1) includes the production costs of row crops, perennial crops and crop/forest residues collected for biofuel production, and land conversion costs for marginal lands converted to the production of perennial crops. The land allocated to row crops and perennial crops (acreage) in region $r$ and year $t$, denoted by $A C R_{t, r, q}$ and $A C R_{t, r, p}$, respectively, may use one of the various production practices which differ by crop rotation, tillage, and irrigation. Fixed input-output coefficients (Leontief production functions) are assumed for both row crops and perennial crops production. The third term represents the cost of collected crop residues (biomass for cellulosic biofuel production) and involves the management options for row crops that produce biomass (specifically, corn stover and wheat straw). The amount of marginal lands converted for perennial grasses are denoted by $\triangle A C R_{t, r, p}$ and $c c_{r}$ represents the cost per unit of marginal land conversion. The last term denotes the costs of converted marginal 
lands (such as idle land and crop pasture land) for perennial crops. The land conversion costs include costs for land clearing, wind rowing and any necessary activities for seedbed preparation.

The third line in (1) includes the costs associated with livestock activities. The amount of livestock is represented by $L I V_{t, k}$, and $l c_{k}$ denotes the cost per unit of livestock category $k$ (again employing Leontief production functions) that is assumed to be the same across all regions. The second term represents the total cost of converting primary crops (corn, soybeans, and sugarcane) to secondary (processed) commodities (oils, soymeal, refined sugar, HFCS and DDGS). The amount of processed primary crop $i$ in year $t$ is denoted by $P R O_{t, i}$, and $s c_{i}$ denotes the processing cost per unit of $i$.

The fourth line involves the costs accruing to the fuel sector. The first integral represents the area under the supply functions for gasoline from domestic producers and the rest of the world, whose consumption and price are to be determined endogenously. The next two terms represent the processing costs of corn and cellulosic ethanol in refinery, namely $E T H_{t, c}, E T H_{t, b}$. Finally, the last line reflects the value of the remaining economic life of standing perennial grasses beyond the planning period $T$, denoted by $v_{r, p}$, net of the return from the most profitable cropping alternative in region $r$, denoted by $w_{r}$. The latter is used to account for the opportunity costs of land.

In the model, we assume that the consumers obtain utility from VKT $\left(K I L_{t}\right)$, which is produced by blending gasoline $\left(G A S_{t}\right)$, corn ethanol $\left(E T H_{t, c}\right)$, cellulosic ethanol $\left(E T H_{t, b}\right)$ and sugarcane ethanol $\left(I M P_{t, s}\right)$. Gasoline and ethanol are assumed to be imperfect substitutes in kilometers production while corn ethanol and cellulosic ethanol are perfect substitutes. The total 
amount of kilometers generated by use of all sources of fuels is formulated using a constant elasticity production function as shown in equation (2) below:

$$
K I L_{t}=\gamma_{t}\left[\alpha_{t}\left(E T H_{t, c}+E T H_{t, b}+I M P_{t, s}\right)^{\rho}+\left(1-\alpha_{t}\right) G A S_{t}^{\rho}\right]^{1 / \rho} \text { for all } t
$$

The regional material balance equations link the production and usage of primary crops, as shown in constraint (3) for primary crop product $i$ produced and marketed by region $r$ :

$$
M K T_{t, r, i}+\left\{C E_{t, r}\right\}_{\mid i=c o r n} \leq \sum_{j} y_{r, q, i} A C R_{t, r, q} \text { for all } t, r, i
$$

where $M K T_{t, r, i}$ denotes the amount of primary crop product $i$ sold in the commodity markets and $y_{r, q, i}$ is the yield of product $i$ per unit of the land allocated to crop production activity $q$ in region $r$. For corn, $M K T_{t, r, i}$ includes non-ethanol uses and $C E_{t, r}$ is the amount of corn converted to ethanol production (which appears only in the balance constraint for corn).

The amount of primary crop $i$ available in the market (excluding the corn used for ethanol) comes from domestic regional supply $\left(M K T_{t, r, i}\right)$. This total amount is either consumed domestically $\left(D E M_{t, i}\right)$, exported $\left(E X P_{t, i}\right)$, processed to secondary commodities $\left(P R O_{t, i}\right)$, or used for livestock feed $\left(F E D_{t, i}\right)$. This is expressed in constraint (4) below:

$$
D E M_{t, i}+P R O_{t, i}+F E D_{t, i}+E X P_{t, i} \leq \sum_{r} M K T_{t, r, i} \text { for all } t, i
$$

Similar to (4), a balance equation is specified for each processed commodity. Like primary commodities, processed commodities can also be consumed domestically, exported, or fed to animals, as shown in constraint (5) below:

$$
D E M_{t, j}+F E D_{t, j}+E X P_{t, j} \leq v_{i, j} P R O_{t, i}+\left\{\sum_{r} v_{i, j} C E_{t, r}\right\}_{j=d d g, i=c o r n} \text { for all } t, j
$$

where $v_{i, j}$ denotes the conversion rate of raw product $i$ to processed product $j$. 
A particularly important component of the model that links the crop and fuel sectors is the conversion of corn and cellulosic biomass to ethanol. During the conversion of corn a secondary commodity, called the Distiller's Dried Grains with Solubles (DDGS), is produced as a byproduct. The amount of DDGS produced is proportional to the amount of corn used for ethanol, $C E_{t, r}$, through a fixed conversion rate $v_{c o r n, d d g}$, and it can either be fed to livestock as a substitute for soymeal or exported.

The relations between ethanol production and crop production activities are expressed below:

$$
\begin{aligned}
& E_{t, c}=\alpha \sum_{r} C E_{t, r} \quad \text { for all } t \\
& E_{t, b}=\beta\left(\sum_{r, p} b y_{r, p} A C_{t, r, p}+\sum_{r, q} r y_{r, q} A C_{t, r, q}\right) \quad \text { for all } t
\end{aligned}
$$

where $\alpha$ and $\beta$ denote the amounts of ethanol produced per unit of corn and cellulosic

feedstock, respectively, and $b y_{r, p}$ and $r y_{r, q}$ are the biomass and crop residue yields in region $r$ for respective perennial and crop production activities.

Land is the only primary production factor considered in the model. In each region, the total amount of land used for all agricultural production activities cannot exceed the available land $\left(a l_{t, r}\right)$, which is specified separately for irrigated and non-irrigated land. Due to the steady increase in ethanol consumption the demand for agricultural land is expected to increase through the conversion of some marginal lands (not currently utilized) to cropland. The extent of conversion is assumed to depend on variations in crop prices over time. Therefore, in the model we determine the agricultural land supply 'endogenously'. Specifically, for a given year $t$ in the planning horizon 2007-2022, we solve the model assuming a fixed regional land availability for each year of the 10-year production planning period considered in that run. From the resulting 
multi-year equilibrium solution, we take the first-year values of the endogenous commodity prices and use them to construct a composite commodity price index, CPI. Based on the CPI generated thereby we adjust the land availability for the subsequent run (which considers another 10-year planning period starting with year $t+1)$. The land constraint is shown in (8).

$$
\sum_{q} A C R_{t, r, q}+\sum_{p} A C R_{t, r, p} \leq a l_{t, r} \quad \text { for all } t, r
$$

To prevent unrealistic changes and extreme specialization in land use, which may be particularly serious at regional level, we restrict farmers' planting decisions to a convex combination (weighted average) of historically observed acreage patterns $\left(h_{r, h t, i}\right)$ where subscript $h t$ stands for the observed time periods prior to the base year. Historical land uses may be valid when simulating farmer's planting decisions under 'normal' conditions. However, they maybe too restrictive for future land uses given the increased demand for ethanol and unprecedented land use patterns that are likely to occur in the future to produce the required biomass crops. To address this issue we introduce 'hypothetical' acreage patterns $\left(h_{r, n, i}^{\prime}\right)$ for each row crop and each region. To generate hypothetical acreage patterns (crop mixes), we first use the historical data on prices and acreages of row crops in each region to estimate acreage elasticities for each row crop with respect to its own price and cross-price changes while controlling other factors, such as social- economic changes and time trend. Then we estimate a number of hypothetical acreages using these price elasticities and considering a systematically varied set of crop prices. The resulting set of actual and hypothetical crop mixes are used in constraint (9) to limit the flexibility in planting decisions, where $\theta_{i, q}$ represents the share of row crop $i$ in production activity $q$ and $W_{t, r, *}$ represents the weight assigned to historical or hypothetical crop mixes. The latter are defined as variables to be endogenously determined by the model. 
$\sum_{q} \theta_{i, q} A C R_{t, r, q}=\sum_{h t} h_{r, h t, i} W_{t, r, h t}+\sum_{n} h_{r, n, i}^{\prime} W_{t, r, n} \quad$ for all $t, r, i$

The sum of the endogenous weights assigned to individual mixes must be less than or equal to 1 (convexity requirement), as shown in equation (10).

$$
\sum_{\tau} W_{t, r, \tau}+\sum_{n} W_{t, r, n} \leq 1 \quad \text { for all } \mathrm{t}, \mathrm{r}
$$

A similar set of crop mix constraints is introduced for irrigated crops too, which we do not show here, using only the historically observed irrigated land use patterns (no hypothetical mixes for irrigated crops).

Large scale monocultures of perennial grasses may have unforeseen impacts on biodiversity and sub-surface water flows. To prevent extreme specialization in the production of perennial grasses in some regions, we restrict the land allocated to perennial grasses to less than $25 \%$ of total land available in each region $\left(a l_{t, r}\right)$. The constraint is shown in (11).

$$
\sum_{p} A C R_{t, r, p} \leq 0.25 * a l_{t, r} \quad \text { for all } t, r
$$

In the livestock sector, we define production activity variables (number of animals) at national level for each category of livestock except the beef and dairy cattle. Cattle production is given special emphasis in the model for two reasons. First, cattle require grazing land, therefore compete with crop production activities on total land in each region. Second, besides requirements of feed crops directly fed to different types of livestock, DDGS (a byproduct of corn ethanol production) is also used as a feed item that may substitute soymeal (both supplying protein). The regional cattle production activities are aggregated in (12) to obtain the total cattle activity at national level:

$$
L I V_{t, \text { cattle }}=\sum_{r} C T L_{t, r} \text { for all } t
$$


where $C T L_{t, r}$ is the number of cattle stock in region $r$ and year $t$. Cattle supply is constrained by the grazing land availability. Therefore, for each region we specify the grazing rates and the supply of grazing land, $G L_{t, r, g}$, where $g$ denotes the type of grazing land (namely pasture land, forest land and cropland that can be used for grazing -such as wheat and oats). The amounts of other livestock (chicken, turkey, lamb, pork and eggs) are also constrained by historical numbers at the national level. Constraint (13) below relates the usage of grazing land and cattle activity in each region:

$$
C T L_{t, r} \leq \sum_{g} G L_{t, r, g} / g a_{r, g} \text { for all } t, r
$$

where $g a_{r, g}$ denotes the amount of grazing land required per unit of cattle.

Equations (14) and (15) establish the balances between nutrition needs of livestock activities, in terms of protein and calories, and the amounts of nutrients provided by primary feed crops (grains) and byproducts of crops processing (i.e., soymeal and DDGS):

$$
\begin{aligned}
& n r_{k, n u} L I V_{t, k}=\sum_{i} n c_{i, n u} F_{t, i, k}+\sum_{j} n c_{j, n u} F_{t, j, k} \text { for all } \mathrm{t}, \mathrm{k} \\
& F E D_{t, z}=\sum_{k} F_{t, z, k} \text { for all } t, k \text { and } z=i, j \text { used for feed }
\end{aligned}
$$

where $n c_{z, n u}$ denotes the nutrition content per unit of feed item $z$, and $n r_{k, n u}$ and $F_{t, z, k}$ are the required amount of nutrient nu per unit of livestock and the amount of feed item $z$ used by livestock category $k$, respectively.

To avoid unrealistic changes in feed mixes, we impose historical feed mixes used by all livestock categories. Constraints (16) and (17) constrain the consumption of feed to be within a convex combination of historical feed uses.

$$
F E D_{t, z}=\sum_{h t} h f_{z, h t} W F_{t, h t}
$$




$$
\sum_{h t} W F_{t, h t} \leq 1
$$

Soybean meal and DDGS are substitutes in the provision of protein up to a certain share level. Because the share of DDGS in total feed consumption of each livestock category is restricted (Babcock et al, 2008), we impose appropriate upper bounds for DDGS to reflect this aspect of feeding practices. Livestock commodities can be consumed domestically or exported. The total supply of each livestock commodity is then related to the respective livestock production activity through a fixed yield coefficient, denoted by $l y_{k, s}$. Constraint (18) establishes this relationship:

$$
D E M_{t, k}+E X P_{t, k} \leq \sum_{s} l y_{k, s} L I V_{t, s} \text { for all } t, k
$$

\section{Data}

The simulation model uses CRD specific data on costs of producing crops, livestock, biofuel feedstocks, yields of conventional and bioenergy crops and land availability. We estimate the rotation, tillage and irrigation specific costs of production in 2007 prices for 15 row crops (corn, soybeans, wheat, rice, sorghum, oats barley, cotton, peanuts, potatoes, sugarbeets, sugarcane, tobacco, rye and corn silage) and three perennial grasses (alfalfa, switchgrass and miscanthus) at county level. These are aggregated to the CRD level for computational ease. Production of dedicated energy crops is limited to the rainfed regions which include the Plains, Midwest, South, and Atlantic, while conventional crops can be grown in the Western region as well. ${ }^{1}$ The primary livestock commodities considered are eggs and milk. The secondary (or processed) crop and livestock commodities consist of oils from corn, soybeans and peanuts, soybean meal, refined sugar, high-fructose corn syrup (HFCS), wool and meat products such as

\footnotetext{
${ }^{1}$ Western region includes Arizona, California, Colorado, Idaho, Montana, Nevada, New Mexico, Oregon, Utah, Washington and Wyoming; Plains includes Nebraska, North Dakota, Oklahoma, South Dakota, Texas and Kansas; Midwest includes Illinois, Indiana, Iowa, Michigan, Minnesota, Missouri, Ohio and Wisconsin; South includes Alabama, Arkansas, Florida, Georgia, Louisiana, Mississippi and South Carolina; Atlantic includes Kentucky, Maryland, New Jersey, New York, North Carolina, Pennsylvania, Tennessee, Virginia, and West Virginia.
} 
beef, pork, turkey, chicken and lamb. Feedstocks used for biofuel production in the model include corn, corn stover, wheat straw, forest residues, miscanthus and switchgrass.

Dedicated Bioenergy Crops: Miscanthus and switchgrass have been identified as among the best choices for high yield potential, adaptability to a wide range of growing conditions and environmental benefits in the U.S. and Europe (Gunderson, Davis and Jager 2008; Heaton, Dohleman and Long 2008; Lewandowski et al. 2003). Both grasses have high efficiency of converting solar radiation to biomass and in using nutrients and water, and have good pest and disease resistance (Clifton-Brown J, Y-C and TR 2008; Semere and Slater 2007).

Switchgrass is a warm season perennial grass native to North America while Miscanthus is a perennial rhizomatous grass non-native to the U.S. A key concern with a large-scale introduction of a non-native grass, such as miscanthus, is its potential to be an invasive species. The miscanthus variety being evaluated in this study as a feedstock for biofuels is the sterile hybrid genotype Miscanthus $\times$ giganteus that has been studied extensively through field trials in several European countries. Switchgrass stands can have a life-span of 15-20 years in a native state, but in cultivated conditions the U.S. Department of Energy estimates stand-life at 10 years. ${ }^{4}$ In the U.S, miscanthus stands that are more than 20 years old have been observed in experimental fields in Illinois (Heaton, Dohleman and Long 2008). This study assumes a lifespan of 10 years for switchgrass and 15 years for miscanthus.

In the absence of long term observed yields for miscanthus and limited data for switchgrass, we use a crop productivity model MISCANMOD to simulate their yields. The MISCANMOD estimates yields of miscanthus and Cave-in-Rock variety of switchgrass using GIS data, at a $1^{\circ}$ by $1^{\circ}$ scale, on climate, soil moisture, solar radiation and growing degree days 
as model inputs, as described in Jain et al. (2010). The Cave-in-Rock switchgrass cultivar studied here is an upland variety that originated in Southern Illinois and is cold-tolerant and well-suited for the upper Midwest (Lemus and Parrish 2009; Lewandowski et al. 2003). Lowland varieties of switchgrass, like Alamo, are most suited for southern US (Lemus and Parrish 2009). Recent analysis of data from field trials across the U.S. shows that frequency distributions of yield for the upland and lowland varieties were unimodal, with mean ( \pm SD) biomass yields of $8.7 \pm 4.2$ and $12.9 \pm 5.9$ metric tons dry matter per hectare (MT DM/ha) for the two varieties, respectively (Wullschlegera et al. 2010). This is consistent with estimates provided by a review of literature which shows that annual yield of lowland variety of switchgrass ranges between 11-16 MT DM/ ha (Lemus and Parrish 2009) and is about 50\% higher than that of the upland variety. We, therefore, increase switchgrass yields from MISCANMOD by 50\% for all regions other than the Midwest (excluding Missouri) to account for higher yields of the lowland varieties.

The simulated yields show that the post-harvest (delivered) biomass yield of miscanthus is about two times the yield of switchgrass at each location. For each crop, these yields vary from north to south and from west to east in the U.S. Atlantic states have high yields for miscanthus and switchgrass while western states have very low yields due to insufficient soil moisture. Furthermore, southern states have higher yields for miscanthus and switchgrass as compared to northern states. The average delivered yield of miscanthus is the highest in the Atlantic states at 31.6 MT DM/ha followed by the South at 30.2 MT DM/ha, Midwest at 23.8 MT DM/ha and the Plains at 19.8 MT DM/ha. Corresponding estimates for average switchgrass yield are 16.4, 15.2, 10.7, $11 \mathrm{MT}$ DM/ha, respectively. ${ }^{5}$

The costs of producing miscanthus and switchgrass differ over their lifetime, due to lags between time of planting and harvestable yields. Costs of production of miscanthus and 
switchgrass are developed for each year of their lifetime for each CRD and include the costs of inputs including fertilizer, seed and chemicals; machinery required for establishment and harvest of bioenergy crops; and storage and transportation. Cost of land for these crops is implicitly included given a land constraint in the model. The cost of labor, building repair and depreciation, and overhead (such as farm insurance and utilities) are excluded from the costs of production since they are likely to be the same for all crops and would not affect the relative profitability of crops. Costs of bioenergy crops in the first year differ from those in subsequent years because it involves costs of seeding and land preparation to establish the crops. Existing studies vary in their assumptions about input requirements, pre-harvesting, harvesting and storage costs of bioenergy crops. This study constructs low cost and high cost scenarios for the production of the bioenergy crops, and the simulation model will test the sensitivity of the results to these assumptions. The low cost scenario considers a low fertilizer application rate, low replanting probability, high second-year yield, low harvest loss and low harvesting costs while the high cost scenario considers the opposite scenario of production. These are described in Jain et al. (2010). Analysis of the break-even annualized costs of producing these grasses shows that there is considerable spatial variation in the cost of cellulosic feedstocks in the U.S. and that the mix of bioenergy crops will differ across geographic locations. Switchgrass is likely to have relatively lower costs of production in some of the northern Midwestern states (Minnesota and Wisconsin) and southern states (Texas and Louisiana) that have relatively high switchgrass yields while Miscanthus has lower costs in the Southern, Atlantic and central Plain states.

Conventional Crops and Crop Residues: For row crops, we use the historical five year average (2003-2007) yield per hectare for each CRD as the representative yield for that CRD 
(USDA/NASS 2009) under dryland and irrigated land. The yields of corn, soybeans and wheat are assumed to grow over time at the trend rate estimated using historical data. These yields are also assumed to be price-elastic with the price elasticities estimated econometrically. The trend rates and elasticities used in the model and more details of the econometric estimation methods can be found in Huang and Khanna (2010). Some crops are grown in rotation with each other to increase soil productivity and reduce the need for fertilizers. We adjust crop yields per hectare based on crop rotations for each CRD. We obtain 15 crop rotation possibilities for each region of the U.S. from USDA/ERS (1997), including corn-soybean rotation, continuous corn rotation, fallow-wheat rotation and continuous rotations for other crops. In Midwestern states where a corn-soybean rotation is the dominant rotation practice, we assume observed corn yields to be those under a corn-soybean rotation. Corn yields per hectare under a continuous corn rotation are assumed to be $12 \%$ lower than under a corn-soybean rotation. The fallow-wheat rotation is primarily used to conserve soil moisture over a 2-year period for 1 year production, which leads to a reduction in wheat yields by $50 \%$ in this rotation. The fallow-wheat rotation is widely used in the Northern wheat-growing region (such as Washington, Oregon, Idaho, Montana and Colorado) and in parts of the Northern Plains states (such as North Dakota, South Dakota, Nebraska and Kansas). Some counties in Minnesota and Texas also use the fallow-wheat rotation. ${ }^{6}$

Corn stover and wheat straw yields for each CRD are obtained based on a 1:1 grain-toresidue ratio of dry matter of crop grain to dry matter of crop residues and $15 \%$ moisture content in the grain reported in Sheehan et al. (2003), Wilcke and Wyatt (2002) and Graham, Nelson and Sheehan (2007). Similar to Malcolm (2008), we assume that 50\% of the residue can be removed from fields if no-till or conservation tillage is practiced and 30\% can be removed if till or 
conventional tillage is used. Corn stover yield ranges from 0.16-5.07 MT DM/ha under no-till while wheat straw yield ranges from 0.34 to $4.38 \mathrm{MT}$ DM/ha in the U.S. In contrast to miscanthus, the average delivered yields for corn stover are the highest in Midwestern and Plain states at $4.0 \mathrm{MT} / \mathrm{ha}$ followed by the southern and western states at 3.3 and $3.2 \mathrm{MT} / \mathrm{ha}$ respectively. Atlantic states have the lowest corn stover yield at 2.8 MT/ha. Wheat straw delivered yield is highest in the West at $3.1 \mathrm{MT} /$ ha followed by the Midwestern states at 2.3 MT/ha and less than $2 \mathrm{MT} / \mathrm{ha}$ in other regions.

Costs of producing row crops and alfalfa are obtained from the crop budgets complied for each state by state extension services and used to construct the costs of production for each CRD. Crop budgets vary by rotation, tillage and irrigation choices. The costs of crop production include costs of inputs such as fertilizer, chemicals and seeds, costs of drying and storage, interest payments on variable inputs, costs on machinery and fuels and costs of crop insurance. The costs of labor, building repair and depreciation, and overhead (such as farm insurance and utilities) are excluded from these costs of production since they are likely to be the same for all crops and would not affect the relative profitability of crops. We determine the cost of production of corn silage by estimating the foregone revenue per hectare by growing corn silage instead of corn, the additional cost of fertilizer replacement that is needed for corn silage, and harvesting costs as reported in $\mathrm{FBFM}^{7}$.

Application rates for nitrogen, phosphorous and potassium and seeds for row crops and alfalfa vary with crop yields, and differ across CRDs. Other costs of producing crops are assumed to be fixed irrespective of crop yields per hectare but differ across states. In addition, costs of fertilizer, chemicals and machinery under conventional tillage differ from those under conservation tillage. 
The costs of collecting corn stover and wheat straw include the additional cost of fertilizer that needs to be applied to replace the loss of nutrients and soil organic matter due to removal of the crop residues from the soil. The fertilizer application rates per dry metric ton of stover and straw removed are assumed to be constant across regions and are obtained from Sheehan et al. (2003) and Wortmann et al. (2008), respectively. In addition, the collection of crop residues involves the costs of harvesting stover and staw (i.e., mowing, raking, baling, staging and storage) that are estimated based on the state-specific crop budgets on hay alfalfa harvesting. We find that the costs of production of crop residues are higher than those of bioenergy crops grown on marginal lands, except for corn stover in Plain states, such as North Dakota, South Dakota and Nebraska where corn yields are high due to irrigation. High wheat yields in western mountain states (such as in Oregon, Idaho and Washington) can make wheat straw in those states competitive with other biomass produced in rain-fed eastern US.

Land Availability: For each of the five types of land (cropland, idle cropland, cropland pasture, pasture land and forestland pasture) we obtain CRD-specific data on land availability. CRDspecific planted acres for 15 row crops are used to obtain the cropland available in 2007 (estimated at $123 \mathrm{M}$ ha for the $280 \mathrm{CRDs}$ considered here), and to obtain the historical and synthetic mixes of row crops. Cropland availability in each CRD is assumed to change in response to crop prices. The responsiveness of total cropland to crop prices as well as the own and cross-price acreage elasticities for individual crops are obtained from Huang and Khanna (2010).

Data on idle cropland, cropland pasture, pasture and forestland pasture for each CRD are obtained from USDA/NASS (2009). In 2007, the availability of pastureland and forestland 
pasture is estimated to be $155 \mathrm{M}$ ha and $10.5 \mathrm{M}$ ha, respectively while that of idle cropland is 15 $\mathrm{M}$ ha and of cropland pasture is $13 \mathrm{M}$ ha. Most of the idle cropland in 2007 was enrolled in the Conservation Reserve Program (CRP). This size of the CRP decreased to $13 \mathrm{M}$ ha from 2008 onwards. The analysis here assumes that land enrolled in CRP is preserved at 2008 levels and not used for conventional crop or bioenergy crop production.

Crop and Livestock Sector: In the livestock sector we consider demands for several types of meat (chicken, turkey, lamb, beef and pork), wool, dairy and eggs. The demand functions are calibrated using the observed quantities consumed and prices and demand elasticities. The latter are obtained from Adams et al. (2005). The supply of livestock (chicken, turkey, lamb and pork) is constrained by their historical numbers at the national level. The supply of beef is restricted by the number of cattle which in turn depends on the amount of grazing land available at regional level. The historical livestock data at the national level and production of meat, dairy and eggs for 2003-2007 are used to obtain the average livestock productivity. The data on grazing land requirements for cattle, nutrition requirements (in terms of protein and grain) for each livestock category, and production and processing costs are obtained from Adams et al. (2005). We use the nutrient content of feed crops, soymeal and DDGS to find the least cost feed rations for each type of livestock. The price of DDGS is determined by the lagged prices of corn and soymeal using the relationship estimated by Ellinger (2008). To prevent unrealistic feed mixes consumed by livestock we constrain the consumption of different types of feed based on the historically observed levels obtained from USDA/NASS (2009).

The crops sector consists of markets for primary and processed commodities. The demands for primary commodities, such as, corn and soybeans are determined in part by the demands for processed commodities obtained from them and by other uses (such as seed). The 
conversion rates from primary crop commodities to processed commodities are obtained from USDA/NASS (2009). Conversion costs are obtained from Adams et al. (2005) and inflated to 2007 prices using the respective GDP deflator. We use two-year (2006-2007) average prices, consumption, exports and imports of crop and livestock commodities to calibrate the domestic demand, export demand and import supply functions for all commodities ${ }^{8}$. The data on prices, consumption, exports and imports are obtained from ERS/USDA. Elasticities are assembled from a number of sources including FASOM, USDA and existing literature as shown in Table 1. Domestic demands, export demands and import supplies are shifted upward over time at exogenously specified rates, listed in Table 1 . We obtain projected amounts of crop and livestock commodities for domestic consumption, exports and imports for 2010 and 2020 from FAPRI ${ }^{9}$ and interpolate then for the intervening years assuming a uniform annual growth rate.

Fuel Sector: We assume a linear demand function for VKT with a price elasticity of -0.2 that shifts out by $1 \%$ each year ${ }^{10}$. The elasticity of substitution between gasoline and ethanol is 3.95 (Hertel, Tyner and Birur 2008). For the supply of gasoline, we consider two gasoline supply curves to distinguish domestic gasoline supply and gasoline supply from the rest of the world. The short-run supply of domestic gasoline is assumed to be linear with a slope of 0.9 (Greene and Tishchishyna 2000) implying a short-run supply elasticity of 0.049 when the oil price is \$34/BBL while the short-run gasoline supply to the U.S. from the rest of the world is assumed to have a constant elasticity form with a price-elasticity of 2 (National Research Council 2002).

To calibrate the demand function of vehicle kilometers, production function of vehicle kilometers and supply functions of gasoline, data on consumption of kilometers and fuel consumption and fuel prices in 2007 are assembled from several sources. The Federal Highway 
Administration (FHWA) reports that total vehicle-kilometers traveled in 2007 were 5107 B kilometers. The Energy Information Administration (EIA) reports that the consumption of gasoline and ethanol are 519.4 B liters and 23.4 B liters, respectively, in the U.S. in 2007. The EIA reports that average retail price of gasoline that year was $\$ 0.72$ per liter. We calculate the retail price of ethanol as the wholesale rack price plus $\$ 0.10$ per liter fuel taxes and a $\$ 0.05$ per liter markup minus $\$ 0.13$ per liter subsidy, yielding $\$ 0.61$ per liter in $2007^{11}$. In the benchmark case we assume the price elasticity of VKT demand is -0.2 and elasticity of substitution between gasoline and ethanol is 3.95 (Hertel, Tyner and Birur 2008).

We assume linear supply functions for ethanol imports from Brazil and CBI countries, and use two-year (2006-2007) average prices and imports of ethanol imports to calibrate the ethanol import supply functions. The excess supply elasticity of imported ethanol from Brail and CBI counties is assumed to be 2.7 (as in de Gorter and Just (2008)). We calculate the sugarcane ethanol price in Brazil and CBI countries as U.S. retail price minus $\$ 0.02$ per liter transportation cost, fuel tax and tariff, and plus subsidy, yielding $\$ 0.49$ and $\$ 0.62$ per liter, respectively. ${ }^{12}$

Ethanol yield from corn grain is 417.3 liters of denatured ethanol per metric ton of corn while cellulosic biofuel yield from an nth-generation stand alone plant is estimated as 330.5 liters per metric ton of dry matter of biomass (Wallace et al. 2005). The cost of conversion of corn grain to ethanol is estimated as $\$ 0.20$ per liter in 2007 prices based on EPA estimates (EPA 2010) while the non-feedstock costs of producing cellulosic ethanol are estimated as $\$ 0.37$ per liter in 2007 prices (EPA 2010). We assume that the current unit cost of conversion of feedstock to biofuel, $C_{\text {cum }}$, is a declining function of cumulative production, i.e., $C_{\text {cum }}=C_{0} \mathrm{Cum}^{b}$, where $C_{0}$ is the cost of the first unit of production, Cum is the cumulative production, $b$ is the experience index. We assume $b$ for corn ethanol is equal to -0.20 (Hettinga et al. 2009) and calibrate $C_{0}$ 
using data on the processing cost and cumulative corn ethanol production in 2007. To calibrate the function for cellulosic ethanol we assume $C_{\text {cum }}$ in 2022 is $\$ 0.18$ per liter (EPA 2010) and use the production quantities specified in the RFS to obtain a value for $b$ of $-0.05 .{ }^{13}$ The feedstock and refinery costs of sugarcane ethanol in Brazil and CBI countries are also assumed to be declining functions of cumulative production. We assume $b$ for sugarcane ethanol is -0.32 (van den Wall Bake et al. 2009). Parameter $C_{0}$ is calibrated using data on the feedstock and refinery costs of sugarcane ethanol and cumulative sugarcane ethanol production in 2007. The growth rate of sugarcane ethanol production is assumed to be constant and equal to 8\% (van den Wall Bake et al. 2009) and is used to compute the feedstock and refinery costs of sugarcane ethanol for 2007-2022.

\section{Results}

We first validated the simulation model assuming existing fuel taxes and corn ethanol tax credits and compared the model results on land allocation, crop production, biofuel production, and commodity prices with the corresponding observed values in the base year (2007). Since the corn ethanol mandate was exceeded in 2007 it is not imposed as a binding constraint. As shown in Table 2, the differences between model results and the observed land use allocations are less than $10 \%$. Food prices are generally within $10 \%$ of the observed values except for the wheat price which is $12 \%$ higher than the actual prices in 2007 . The fuel prices and fuel consumption are also simulated well, within $5 \%$ deviation from the observed values. We consider these results as a fairly good sign of the model's validation capability.

We then examine the effects of two policy scenarios on the agricultural and fuel sectors: biofuel mandates under the RFS alone, and biofuel mandates with volumetric tax credits. The RFS mandates are set as nested volumetric requirements for the production of biofuels at 
mandated levels for the period of 2007-2022. These mandates serve as the minimum quantity restrictions on biofuel production that can shift up if economically competitive with conventional fuels through policy support and technological improvements. We then compare model results under biofuel policies to those under a business-as-usual (BAU) scenario. The BAU scenario is defined as one without any biofuel policy, except for the tariff on biofuel imports which is kept unchanged in all scenarios here. In all scenarios considered here we also include a fuel tax on gasoline and biofuels, which is set at $\$ 0.10$ per liter, and assume that the demands for crops and VKT increase over time. Results for cropland allocation are presented in Table 3 while Table 4 shows the results for production and prices of key crop and livestock commodities. The regional distribution of land for bioenergy feedstocks are presented in Table 5. Tables 6 and 7 present the impact of biofuel policies on the fuel sector and on social welfare. Table 8 contains the results of the sensitivity analysis.

Business-As-Usual (BAU) Scenario: In the absence of any government intervention in the biofuel market we find that total crop acreage decreases by $0.3 \%$ from 121.5 in 2007 to $121.1 \mathrm{M}$ ha in 2022 with corresponding increases in idle/pasture land. Corn and soybean acreages would decrease by $0.8 \mathrm{M}$ ha (2.8\%) and $0.1 \mathrm{M}$ ha (0.4\%) while wheat acreage would increase by $1.2 \mathrm{M}$ ha (5.3\%) over the 2007-2022 period. Land under cotton in 2022 decreases by $0.3 \mathrm{M}$ ha (7.8\%) compared to 2007. Despite the reduction in corn and soybean acreages, their production would increase by $16 \%$ and $10 \%$ over the $2007-2022$ period due to $19 \%$ and $10 \%$ increases in corn and soybean yields. The production of wheat also increases by $25 \%$, which can be attributed to the increases in wheat acreage and yields from 2.4 metric tons per hectare to 2.8 metric tons per hectare over 2007-2022. In the livestock sector, beef production would increase by 10\% between 
2007-2022. Despite the increasing demand for corn for biofuel production, corn price decreases by $7 \%$ in 2022 due to the increase in corn yields. Since corn is a major source of feed for beef production, it leads to a reduction in beef price in 2022 by $12 \%$ compared to 2007 . Soybean and wheat prices change only marginally between 2007 and 2022. There is a significant increase in exports of corn, soybean and wheat by 31\%, 6\% and 38\% over the 2007-2022. Exports of beef would increase by $30 \%$ due to lower beef prices.

In the fuel sector, we find an $8 \%$ increase in the price of VKT and a $7 \%$ increase in gasoline price in 2022 compared to 2007. Ethanol consumption would be about $28 \mathrm{~B}$ liters in 2022 or $4 \%$ of fuel consumed with no government intervention. Of the cumulative consumption of corn ethanol over the 2007-2022 period, a little over 10\% is imported from Brazil.

Biofuels Mandate: With corn ethanol production at its maximum allowable level or 56 B liters from 2015 and beyond, it could constitute a maximum of two-thirds of the cumulative biofuel production between 2007-2022; the remaining mandate is met by advanced biofuels. With the nested volumetric provisions of the RFS, however, advanced biofuels can meet more of the mandate than the minimum level if they can compete with corn ethanol. Given the assumptions about the rate of decline in costs of producing advanced biofuels from cellulosic feedstocks in the US (described above), we find that the RFS would lead to the production of about $613 \mathrm{~B}$ liters of corn ethanol and about $608 \mathrm{~B}$ liters of advanced biofuels including $38 \mathrm{~B}$ liters of sugarcane ethanol imports over the 2007-2022 period. This would increase cumulative production of corn ethanol by $107 \%$ relative to the BAU over this period. The cumulative advanced biofuels (608 B liters) are largely produced using miscanthus (49\%) and forest residues (22\%), with the rest produced using switchgrass, corn stover and wheat straw. 
The RFS leads to a 6\% increase in total cropland (6.86 M ha); most of this is to enable an increase in corn production to produce the additional corn ethanol. There is a $16 \%$ increase (about 4.7 M ha) in land under corn in 2022 compared to the BAU. With a high yielding grass like miscanthus, only $4.4 \mathrm{M}$ ha are required for miscanthus production and $3 \mathrm{M}$ ha to switchgrass production to produce cellulosic biofuels. Of this $7.44 \mathrm{M}$ ha under bioenergy crops only $0.44 \mathrm{M}$ ha is converted from cropland and about 7M ha is from currently idle cropland or cropland pasture. Thus, a total $12.14 \mathrm{M}$ ha is required for biofuel production; of this, about $5 \mathrm{M}$ ha of land is released by reducing acreage under other crops (including soybeans, wheat, rice, cotton and pasture), representing $4 \%$ of the $121.5 \mathrm{M}$ ha of cropland in 2007 and the rest is obtained by a change in land use at the extensive margin. Corn stover and wheat straw would be harvested from $10 \%$ and $5 \%$ of the land under corn and wheat, respectively, in 2022.

There is considerable variation in the mix of feedstocks produced across regions. Stover is harvested only in the Plain States while wheat straw is harvested mainly in the Western States. More than half of the switchgrass acreage is in the Plain states, followed by the Midwest and the South. Miscanthus acreage is largely in the Plains and the Midwest followed by the Atlantic and Southern States. This acreage also changes over time; it expands as the mandate requires more cellulosic biofuel production. Figure 1 shows the change in land under bioenergy crops over the 2007-2022 period under the mandate. Acreage under miscanthus expands from less than $1 \mathrm{M}$ ha in 2012 to over $4 \mathrm{M}$ ha in 2022. Initially miscanthus and switchgrass acreage are similar as each is produced in areas where it has a comparative advantage; in latter years miscanthus acreage expands much more rapidly while switchgrass acreage levels off because of the relatively lower costs of producing a high-yielding crop like miscanthus. 
The RFS would significantly affect production, exports and prices of crop and livestock commodities. The increase in demand for corn results in an increase in corn production in 2022 by $18 \%$ relative to the BAU. However, corn price in 2022 is still $24 \%$ higher than under the BAU because 38\% of corn production in 2022 is used for biofuel production. Soybean and wheat prices in 2022 are also 20\% and 7\% higher than the BAU due to 8\% reduction in their production levels. The production of rice and cotton in 2022 would decrease by $8 \%$ and $2 \%$, respectively, relative to the BAU due to the acreage shifts to the production of corn. This increases rice and cotton prices in 2022 by 5\% and 2\% relative to the BAU. Livestock prices also rise with beef price increasing by $8 \%$ compared to the BAU due to the increases in feed prices and a $3 \%$ reduction in beef production. In response to higher prices of crop commodities, export of corn, soybean and wheat would decrease by $4 \%, 11 \%$ and $12 \%$ relative to the BAU while the exports of rice would decrease by $42 \%$. Higher livestock prices also lead to a reduction in beef exports by $2 \%$ relative to the BAU.

As a result of the mandate, the volumetric share of ethanol in total fuel consumption increases to $21 \%$ in 2022 . The RFS results in a reduction in cumulative gasoline consumption over the $2007-2022$ period by $7 \%$ and a reduction in gasoline price in 2022 by $8 \%$ compared to the BAU. While domestic gasoline production falls by $2.5 \%$ gasoline imports from the rest of the world decrease by $8.5 \%$ relative to BAU. The overall cost of VKT falls from $\$ 0.087 / \mathrm{km}$ to $\$ 0.085 / \mathrm{km}$; as a result the VKT increases by $0.4 \%$ relative to the BAU scenario in 2022 . This market-based feedback effect on gasoline prices tempers the extent to which biofuels replace gasoline. At a maximum, with perfect substitutability between gasoline and biofuels and a fixed price of gasoline, the additional 109 B liters of biofuels produced in 2022 (over and above the 28 B liters in the BAU) could have displaced an energy equivalent volume of $72 \mathrm{~B}$ liters of gasoline. 
With imperfect substitutability and the reduction in gasoline price, the amount of gasoline reduced is $68 \mathrm{~B}$ liters; implying a rebound effect on gasoline consumption of about $6 \%$.

Biofuel Mandate and Volumetric Tax Credits: The provision of tax credits for biofuels leads to three significant impacts on total biofuel production and the mix of feedstocks used for biofuels. First, it increases total biofuel production over 2007-2022 from the minimum mandated level of 1221 B liters to 1316 B liters. Second, it makes cellulosic ethanol competitive with corn ethanol and sugarcane ethanol and reduces cumulative corn ethanol production from 613 B liters under a mandate alone to $132 \mathrm{~B}$ liters. Cumulative cellulosic ethanol production increases to twice the level under a mandate alone, from 570 B liters to 1159 B liters over the 2007-2022 period. Third, it increases the share of miscanthus and switchgrass in cumulative advanced biofuels (cellulosic biofuels plus sugarcane ethanol) from $49 \%$ and $18 \%$ under a mandate alone to $57 \%$ and $21 \%$. The corresponding shares of ethanol imports and biofuel produced from forest residues fall from $6 \%$ and $22 \%$ under a mandate alone to $2 \%$ and $13 \%$. The reduction in production of corn ethanol (relative to the RFS) reduces the acreage under corn by $8.4 \mathrm{M}$ ha. Of this, about $6 \mathrm{M}$ ha is diverted to other conventional crops while the rest is diverted to miscanthus and switchgrass. In addition to this, $10.6 \mathrm{M}$ ha of idle/cropland pasture is converted to produce these energy crops. The increase in biofuels produced from miscanthus leads to an increase in the land under miscanthus from 4.4 M ha under a mandate alone to $8.7 \mathrm{M}$ ha under a mandate and volumetric tax credits and a corresponding increase in land under switchgrass from $3 \mathrm{M}$ ha to $4.2 \mathrm{M}$ ha. Switchgrass acreage expands in all rainfed regions as does miscanthus acreage. In particular, these tax credits enable miscanthus acreage to more than double in the Midwest and to expand by more than $50 \%$ in the Atlantic States. The biofuel tax credits also increase the acreage from which 
corn stover and wheat straw are harvested in 2022, to $40 \%$ of corn acres and $9 \%$ of wheat acres, respectively. With the tax credits, it is profitable to harvest corn stover in the Midwest and to harvest wheat straw in the Plains and Southern States. Switchgrass acreage expands in all rainfed regions as does miscanthus acreage. The expansion in acreage of energy crops over time is much more rapid for miscanthus than for switchgrass (Fig.1). The volumetric tax credits also make the production of switchgrass and miscanthus viable earlier than otherwise. Moreover, they change the relative profitability of growing miscanthus and switchgrass. After 2016, miscanthus acreage continues to expand while switchgrass acreage levels off and even declines in later years. This is because volumetric subsidies increase the relative profitability of biofuels with higher yields per hectare of land. After 2016, miscanthus and switchgrass compete for marginal land in the same locations and the tax credits increase the relative profitability of miscanthus in those locations.

The change in the composition of biofuels due to the subsidy changes the total land under crop production and under various row crops. Total cropland increases by $1.1 \mathrm{M}$ ha relative to that under the RFS alone, due to an expansion in acreage under energy crops. Acreage under corn and corn production in 2022 declines by 13\% relative to the BAU scenario; corn production in 2022 is, however, still higher than that in 2007 under the BAU due to productivity increase. In comparison to BAU, acreage under soybeans and soybean production in 2022 would increase by $2 \%$ and $3 \%$, respectively. The reduction in total cropland availability results in a decrease of 1.5 M ha in acreage under wheat, rice, cotton and pasture compared to the BAU. However, the acreage under these crops in 2022 under a mandate and subsidy are still higher than those under a mandate alone.

The increase in the production of cellulosic biofuels due to biofuel subsidies alleviates the adverse impact of the mandate on the prices of crop and livestock commodities. Corn and 
soybean prices in 2022 would be $24 \%$ and $16 \%$ lower than under a mandate alone while beef price in 2022 would be 6\% lower. In comparison to the BAU, corn price in 2022 is $6 \%$ lower due to productivity increase and decrease in demand for corn ethanol. Prices of soybeans, wheat, rice and cotton are similar to those under the BAU, deviating from $-1 \%$ for rice to $3 \%$ for wheat. Beef price is about $1 \%$ higher relative to the BAU. In response to lower prices of corn, soybeans and rice, exports demand for these commodities would increase by $0.7 \%, 0.1 \%$ and $2 \%$ relative to the BAU. Lower beef price also leads to an increase in beef exports by $11 \%$ relative to the BAU. The volumetric tax credits result in consumer prices of $\$ 0.54$ per liter for corn ethanol and \$0.46 per liter for cellulosic ethanol that are significantly lower than those under a mandate alone while the gasoline price is marginally higher due to increased demand for fuel relative to the mandate alone. Relative to the RFS alone, cumulative VKT over the 2007-2022 period increases by $581 \mathrm{~B}$ kilometers (0.7\%), while gasoline consumption increases by $4.6 \mathrm{~B}$ liters (0.05\%) and biofuel consumption increases by $95.38 \mathrm{~B}$ liters (8\%). The tax credits lower the overall cost of fuel and thus the cost per kilometer by $6 \%$.

\section{VII.2. Social Welfare Effects of Biofuel Policies}

We use the modeling framework presented here to estimate the changes in consumer and producer surplus in each of the markets in the fuel and agricultural sector considered here and the change in government revenues due to fuel taxes/subsidies. We present the change in social welfare with the RFS compared to the BAU and the change in social welfare with the RFS and volumetric tax credits relative to the RFS alone in Table 7. As described above, the RFS leads to lower gasoline price but higher costs of corn ethanol and cellulosic biofuels; nevertheless it lowers cost per kilometer. Therefore, it increases the consumer surplus of the vehicle kilometer 
consumers. The RFS also raises conventional crop prices and by increasing demand for residues and energy crops it raises returns from existing land as well as from marginal land that was otherwise not used for agricultural production. It, therefore, benefits agricultural producers. This is at the expense of agricultural consumers; only a portion of these are, however, domestic. Thus some of the loss in surplus is borne by foreign consumers. The RFS hurts gasoline producers by lowering demand for gasoline and its price. However, with two-thirds of the cumulative gasoline consumption over the 2007-2022 period being imported, the bulk of the loss in producer surplus is borne by foreign oil producers. As a result, the RFS leads to an increase in net present value of social welfare (in 2007 dollars) of \$122 B relative to the BAU. It also increases cumulative biofuel production relative to the BAU by $890 \mathrm{~B}$ liters, implying a per liter benefit of $\$ 0.14$.

As compared to the RFS, the provision of volumetric tax credits lowers crop prices and the cost per kilometer; therefore, they benefit agricultural consumers and vehicle kilometer consumers. Moreover, they benefit producers of cellulosic feedstocks by further increasing demand for crop residues and energy crops. However, producers of conventional crops are adversely affected as are gasoline producers. There is a significant government expenditure of \$221 B in present discounted value over the 2007-2022 period. As a result, aggregate social welfare is $\$ 79$ B lower than under the RFS alone. Focusing only on tax payer cost of these tax credits would significantly overestimate the cost of additional biofuel production. By estimating welfare cost we consider not only the costs to tax payers but also the net costs to the economy after considering the gains and losses to fuel and crop consumers and producers. The tax credits do lead to additional biofuel production over and above the RFS alone (by 95 B liters, that is by about 8\%) over the 2007-2022 period, implying a welfare cost of $\$ 0.83$ per liter of biofuel. In gasoline energy equivalent terms, this implies a cost of about $\$ 1.25$ per liter. 
Although our estimate of the welfare cost of biofuel is lower than the direct cost to tax payers are per liter cost of additional biofuel is higher than that obtained by the CBO ( ), because the incremental volume of biofuels attributable to the tax credits is lower than their assumption. The low volume of incremental biofuel attributed to the tax credits in this study is due to our assumption that the volume of biofuel mandated by the RFS will be achieved even in the absence of a tax credit. In the event that this is not the case, or if there are other constraints to increasing biofuel production, then the incremental biofuel production due to these tax credits could be smaller or larger than that estimated here. Moreover, the welfare cost of these tax credits cannot be disaggregated into those for corn ethanol and those for cellulosic biofuels since each of these tax credits not only has a direct effect on the particular type of biofuel towards which it is targeted but also indirectly affects the production of the other type of biofuel by changing their relative costs. Thus, it is the combined effect of both the volumetric tax credits for corn ethanol and cellulosic biofuels that together determines the effect on food and fuel prices and on social welfare.

\section{VII.3. Sensitivity Analysis}

We examine the sensitivity of our results to changes in some key assumptions about technology and cost parameters in the agricultural sector (see Table 8), such as, the rate of yield increase of row crops, the costs of producing bioenergy crops and land availability for bioenergy crops. Jain et al.(2010) describe two scenarios for the costs of production of miscanthus and switchgrass, a low cost and a high cost scenarios. The benchmark case considered the low cost of miscanthus and switchgrass production described there. We now examine the implications of the costs of production being less optimistic for miscanthus ${ }^{14}$ than assumed in the benchmark case 
but the same for other feedstocks as in the benchmark case. We also examine the implications of constraining the amount of land in a CRD that can be used for bioenergy crops to $10 \%$ instead of $25 \%$ assumed in the benchmark case. In each case, only one parameter is changed at a time while all other parameters remain the same. We report the results for the biofuel mandate alone (M) and biofuel mandates plus volumetric tax credits (MS) scenarios. We present the percentage variations due to the parameter changes relative to the same policy scenarios with the benchmark parameters.

We find that compared to the benchmark case, a 50\% reduction in rate at which crop productivity reduces the acreage under corn under the RFS by about 5\%, increases corn price by $2 \%$ and decreases the production of corn ethanol by $25 \%$. It increases cellulosic biofuel production by $27 \%$ and acreage under miscanthus and switchgrass increases by $31 \%$ and $7 \%$. This raises the marginal cost of feedstocks for cellulosic biofuel production and makes it profitable to increase the area from which corn stover and wheat straw are harvested by $164 \%$ and 53\%, respectively. The volumetric subsidies now shift land even more towards miscanthus and switchgrass (since they are relatively higher yielding feedstocks) and lowers acreage under corn stover and wheat straw acreages by $9 \%$ and $7 \%$, respectively. Corn and soybean prices are $7 \%$ and $4 \%$ higher than in the benchmark case. The welfare cost of the tax credits is lower than in the benchmark case by $12 \%$ primarily because the producers of conventional crops and of bioenergy crops are better off in this case; the former due to higher crop prices and the latter due to greater demand for cellulosic biofuels. Incremental biofuel production due to the tax credits is higher due to greater imports and the shift towards cellulosic biofuels. As a result the welfare cost per liter of biofuels decreases to $\$ 0.7$. 
Raising the production cost of miscanthus relative to other feedstocks leads to a significant decline in the production of miscanthus and expansion in the use of crop residues and switchgrass to produce cellulosic biofuels. It increases the share of corn ethanol, ethanol from forest residues and of ethanol imports in the cumulative biofuel production under the RFS and under the RFS and tax credit scenario. The price of cellulosic biofuels increases by $16 \%$ but overall impact on VKT and on gasoline consumption is small. There is a 3\% reduction in cumulative biofuel consumption in the MS scenario relative to the benchmark due to the absence of the high yielding feedstock, miscanthus; same level of land under bioenergy crops now yields a lower volume of biofuels. The welfare cost of the tax credits is significantly lower in this case but so is the incremental biofuel production due to the tax credit, resulting in an increase in the per liter welfare cost to $\$ 1.4$.

A reduction in land available for bioenergy crops to a maximum of $10 \%$ of the CRD reduces the share of cellulosic biofuels to meet the RFS by $10 \%$ while increasing the price of cellulosic biofuels by 5\%. Biomass feedstock producers are better off as are row crop producers. The welfare costs of the subsidies are similar to those in the benchmark case, but cumulative biofuel production is 5\% lower than in the benchmark case (by $63 \mathrm{~B}$ liters). As a result the welfare cost of biofuels is substantially higher.

In general, we find that changes in technology and cost parameters that limit the potential to expand production of high yielding biofuels reduce the ability of the volumetric tax credits to significantly increase biofuel production. The tax credits then primarily support biofuel production that occurs anyway to meet the RFS, provided the RFS is binding; resulting in high welfare costs per liter of biofuel production. 


\section{Conclusions and Discussion}

Biofuel mandates and subsidy policies have been enacted with the intention of promoting renewable alternatives to reduce dependence on gasoline. Concerns about the competition they pose for land and its implications for food prices have led to a shift in policy incentives towards second generation biofuels from non-food based feedstocks. This paper develops a framework to examine the economic viability of these feedstocks and the extent to which biofuel expansion will imply a trade-off between food and fuel production. It analyzes the differential incentives provided by alternative policies for biofuel production and the mix of biofuels and the welfare costs of biofuel policies.

Even with the option of high yielding energy crops, we find that a biofuel mandate (without any subsidies) would rely on corn ethanol to meet 50\% of the RFS mandate over 20072022; miscanthus and forest residues would produced $49 \%$ and $22 \%$ of the cumulative advanced biofuels over 2007-2022 with switchgrass, crop residues and ethanol imports meeting the rest. In the benchmark case, the mandate leads to a $16 \%$ increase in corn acreage which is largely met by reducing acreage under soybean and other crops. Despite gains in corn productivity over 20072022 the corn price in 2022 is $24 \%$ higher than in the BAU. In response to higher crop and livestock prices, exports of corn, soybeans, wheat and beef decline relative to the BAU. The mandate lowers the price of gasoline by $8 \%$ in 2022 relative to the BAU which results in a reduction in the cost per kilometer and increases cumulative VKT by $0.4 \%$ over the 2007-2022 period. The benefits to fuel consumers and agricultural producers more than offsets the costs to domestic agricultural consumers and gasoline producers; consequently the RFS raises net present value of cumulative social welfare relative to the BAU by $\$ 122 \mathrm{~B}$. This ranges between $\$ 110$ \$132 across the scenarios considered here. 
Volumetric tax credits for corn ethanol and cellulosic biofuels significantly enhances the competitiveness of cellulosic biofuels relative to corn ethanol and shifts the mix of biofuels such that $88 \%$ of the cumulative biofuels over the 2007-2022 would now be produced from cellulosic feedstocks. This mitigates the competition for land and reduces corn, soybean, wheat, rice, cotton and beef prices relative to those with a mandate alone. Corn price in 2022 would now be $6 \%$ lower than in the BAU. These tax credits lead to substantial reduction in the consumer price of biofuels and in the cost per kilometer, despite marginal increases in the gasoline price. As a result these tax credits benefit fuel consumers, agricultural consumers, gasoline producers and biomass producers. However, they impose significant costs on tax payers and on conventional crop producers (by eventually leading to a transition from corn ethanol to cellulosic biofuels). As a result they lower social welfare relative to the RFS alone. The discounted present value of the welfare costs of these tax credits range between \$79 B and \$118 B over the 2007-2022 period. The incremental gain in total biofuel production beyond the RFS alone ranges between $32 \mathrm{~B}$ liters and 99 B liters across the scenarios considered here. Thus, the welfare cost per liter varies between $\$ 0.7$ per liter and $\$ 2.6$ per liter. These welfare costs are based on the premise that the mandated volume of biofuel production is achieved even in the absence of these tax credits. Moreover, these cost estimates are sensitive to assumptions about the costs of producing cellulosic feedstocks and the extent to which there might be constraints to the expansion of bioenergy crop production on marginal land.

Our analysis also shows the role of productivity enhancing technologies both in the traditional crop sector and the bioenergy sector. Yield increases for major crops like, corn and soybeans and the use of high yielding, long-lived energy crops, like miscanthus contribute to mitigating the competition for land and the impact of biofuel production on food prices. Corn 
price in 2022 would be $2-7 \%$ higher if the rate of productivity growth of row crops is $50 \%$ of that assumed in the benchmark case. High relative costs of miscanthus production result in 14\% lower cumulative cellulosic biofuel production under the RFS and 3\% lower with the RFS and tax credits compared to the corresponding benchmark case.

Our analysis abstracted from considerations of the external benefits of biofuel production in the form of energy security and reduced greenhouse gas emissions relative to gasoline as well as other benefits of ethanol such as its additive value as an oxygenate for gasoline. It does, however, show how high these benefits would need to be to offset the economic welfare costs of tax credits estimated here.

\section{Endnotes:}

\footnotetext{
${ }^{1}$ http://www.agmrc.org/renewable_energy/ethanol/the_relationship_of_ethanol_gasoline_and_oil_prices.cfm\#

${ }^{2}$ http://frwebgate.access.gpo.gov/cgi-bin/getdoc.cgi?dbname=110_cong_public_laws\&docid=f:publ246.pdf

${ }^{3}$ Western region includes Arizona, California, Colorado, Idaho, Montana, Nevada, New Mexico, Oregon, Utah, Washington and Wyoming; Plains includes Nebraska, North Dakota, Oklahoma, South Dakota, Texas and Kansas; Midwest includes Illinois, Indiana, Iowa, Michigan, Minnesota, Missouri, Ohio and Wisconsin; South includes Alabama, Arkansas, Florida, Georgia, Louisiana, Mississippi and South Carolina; Atlantic includes Kentucky, Maryland, New Jersey, New York, North Carolina, Pennsylvania, Tennessee, Virginia, and West Virginia.

${ }^{4}$ http://southwestfarmpress.com/energy/121107-switchgrass-challenges/ http://www.osti.gov/bridge/servlets/purl/771591-9J657S/webviewable/771591.pdf

${ }^{5}$ Delivered yields incorporate losses during harvesting, storing and transporting. Switchgrass yield is typically about one-half of that for miscanthus. Exceptions to this are some northern states and some southern states where switchgrass yields are relatively higher than those for miscanthus because minimum temperature are too low in the north and not low enough in the south for miscanthus growth. Perlaack et al. (2005) assume switchgrass yields of 18 $\mathrm{MT} \mathrm{ha}^{-1}$ in a high yield scenario and $12 \mathrm{MT} \mathrm{ha}^{-1}$ otherwise.

${ }^{6}$ Information on crop rotation for each state is obtained from ERS/USDA report "Production Practices for Major Crops in US Agriculture, 1990-1997”

${ }^{7}$ www.farmdoc.uiuc.edu

${ }^{8}$ An exception is the price of milk which is kept fixed at its observed 2006-2007 level.

${ }^{9}$ http://www.fapri.iastate.edu/outlook/2010/text/Outlook_2010.pdf

${ }^{10}$ We obtain historical data on vehicle kilometers travelled (VKT) from Federal Highway Administration website: http://www.fhwa.dot.gov/policyinformation/statistics/2008/vm202.cfm, and use average growth rate of VMT from 2000-2008.

${ }^{11}$ www.neo.ne.gov/statshtml/66.html

12 Transportation cost of ethanol is estimated to be $\$ 0.02$ per liter in Lasco et al (2010). The difference in ethanol prices in Brazil and CBA countries can be attributed to additional processing cost in CBA countries because ethanol needs to be dehydrated before admitted to the U.S.

${ }^{13}$ These functions imply that the per liter conversion cost for corn ethanol declines by about $27 \%$ while that for cellulosic ethanol declines by $50 \%$ by 2022.

${ }^{14}$ This scenario considers higher fertilizer application rates, lower yields in the second year and higher yield losses during harvest as well as higher harvesting costs per ton.
} 
Table 1: Domestic Demand, Export Demand, Import Supply Elasticities ${ }^{1}$

\begin{tabular}{|c|c|c|c|c|}
\hline Commodity & Uses & Shift (\%) ${ }^{2}$ & Elasticities & Sources \\
\hline \multirow[t]{2}{*}{ Barley } & Domestic & 0.0 & -0.3 & USDA/ERS (2009) \\
\hline & Export & 2.0 & -0.2 & Adams et al. (2005) \\
\hline \multirow[t]{2}{*}{ Corn } & Domestic & 0.8 & -0.23 & Adams et al. (2005) \\
\hline & Export & 2.0 & -0.26 & Fortenbery and Park (2008) \\
\hline \multirow[t]{2}{*}{ Cotton } & Domestic & -2.0 & -0.18 & Adams et al. (2005) \\
\hline & Export & 0.3 & -0.65 & Bredahl et al. (1979) \\
\hline Oats & Domestic & -0.4 & -0.21 & Adams et al. (2005) \\
\hline \multirow[t]{2}{*}{ Sorghum } & Domestic & -1.5 & -0.2 & Adams et al. (2005) \\
\hline & Export & 2.0 & -2.36 & Bredahl et al (1979) \\
\hline \multirow[t]{2}{*}{ Wheat } & Domestic & 1.0 & -0.3 & USDA/ERS (2009) \\
\hline & Export & -2.0 & -1.67 & Bredahl et al. (1979) \\
\hline \multirow[t]{2}{*}{ Soybean } & Domestic & 1.4 & -0.29 & Piggott and Wohlgenant (2002) \\
\hline & Export & 0.4 & -0.63 & Piggott and Wohlgenant (2002) \\
\hline Soybean Meal & Export & 2.0 & -1.41 & Adams et al. (2005) \\
\hline \multirow[t]{2}{*}{ Vegetable Oil ${ }^{3}$} & Domestic & 0.2 & -0.18 & Piggott and Wohlgenant (2002) \\
\hline & Export & 2.0 & -2.24 & Piggott and Wohlgenant (2002) \\
\hline \multirow[t]{2}{*}{ Rice } & Domestic & 2.0 & -0.11 & Gao et al.(1995) \\
\hline & Export & -0.4 & -1.63 & Gao et al.(1995) \\
\hline Peanut & Domestic & 0.8 & -0.25 & Carley and Fletcher (1989) \\
\hline \multirow[t]{2}{*}{ Beef } & Domestic & 0.3 & -0.75 & FAPRI (2009) \\
\hline & Export & 2.0 & -0.8 & Adams et al. (2005) \\
\hline \multirow[t]{2}{*}{ Chicken } & Domestic & 1.4 & -0.46 & Adams et al. (2005) \\
\hline & Export & 1.4 & -0.8 & Adams et al. (2005) \\
\hline Eggs & $\begin{array}{l}\text { Domestic } \\
\text { Export }\end{array}$ & 0.8 & -0.11 & Adams et al. (2005) \\
\hline \multirow[t]{2}{*}{ Pork } & Domestic & 1.0 & -0.83 & Adams et al. (2005) \\
\hline & Export & 2.0 & -0.8 & Adams et al. (2005) \\
\hline \multirow[t]{2}{*}{ Turkey } & Domestic & 0.8 & -0.53 & Adams et al. (2005) \\
\hline & Export & 1.4 & -0.8 & Adams et al. (2005) \\
\hline Lamb & $\begin{array}{l}\text { Domestic } \\
\text { Import }\end{array}$ & 0.0 & -0.4 & Adams et al. (2005) \\
\hline \multirow[t]{2}{*}{ Wool } & Domestic & 0.0 & 0.4 & Adams et al. (2005) \\
\hline & Export & 0.0 & -0.8 & Adams et al. (2005) \\
\hline \multirow[t]{2}{*}{ Refined Sugar } & Domestic & 0.0 & -0.368 & Adams et al. (2005) \\
\hline & Import & 0.0 & 0.99 & Adams et al. (2005) \\
\hline \multirow[t]{2}{*}{ HFCS } & Domestic & 0.5 & -0.91 & Adams et al. (2005) \\
\hline & Export & 2.0 & -0.2 & Adams et al. (2005) \\
\hline
\end{tabular}

Notes:1. This table shows the commodities that can be used for domestic consumption or traded with the rest of the world. Domestic demand for commodities excludes uses for feed and ethanol production, and prices are fixed at 2007 prices if the elasticities are zeros.

2. Demand shifts are computed based on FAPRI 2010 U.S. and World Agricultural Outlook.

3. Vegetable oil includes corn oil, soybean oil and peanut oil. 


\begin{tabular}{lccc}
\hline & Observed & Model & Difference (\%) \\
\hline Total Land & Land Use (M Ha) & \\
Corn & 123.05 & 121.76 & -1.04 \\
Soybeans & 34.31 & 31.12 & -9.30 \\
Wheat & 28.15 & 28.41 & 0.94 \\
Sorghum & 21.52 & 22.46 & 4.38 \\
\hline \multicolumn{4}{c}{ Commodity Prices (\$/MT) } \\
\hline Corn & 142.51 & 133.22 & \\
Soybeans & 303.69 & 319.40 & -6.52 \\
Wheat & 197.31 & 220.33 & 11.67 \\
\hline \multicolumn{4}{c}{} \\
\hline Gas Prices (\$/Liter) & Fuel Sector & \\
Ethanol Prices (\$/Liter) & 0.72 & 0.00 \\
Gas Consumption (B Liters) & 0.61 & 0.61 & -0.49 \\
Ethanol Consumption (B Liters) & 519.94 & 519.34 & -0.11 \\
Kilometers Consumption (B Kms) & 23.51 & 24.22 & 3.02 \\
\hline
\end{tabular}

Table 3: Effect of Biofuel Policies on Land Use in 2022(M Ha)

\begin{tabular}{|c|c|c|c|c|}
\hline & Baseline 2007 & Baseline & Mandate & $\begin{array}{c}\text { Mandate with } \\
\text { Tax Credits }\end{array}$ \\
\hline Total land & 121.51 & 121.13 & 127.99 & 129.06 \\
\hline Corn & 29.74 & 28.91 & 33.55 & 25.14 \\
\hline Soybeans & 29.85 & 29.74 & 27.50 & 30.09 \\
\hline Wheat & 23.02 & 24.24 & 22.25 & 23.35 \\
\hline Stover & & & 3.45 & 10.10 \\
\hline Straw & & & 1.01 & 1.99 \\
\hline Miscanthus ${ }^{1}$ & & & 4.43 & 8.70 \\
\hline Switchgrass $^{2}$ & & & 3.03 & 4.16 \\
\hline
\end{tabular}


Table 4: Effect of Biofuel Policies on Commodity Prices and Production

\begin{tabular}{|c|c|c|c|c|c|c|c|c|}
\hline & \multicolumn{2}{|c|}{ Baseline (2007) } & \multicolumn{2}{|c|}{ BAU (2022) } & \multicolumn{2}{|c|}{ Mandate (2022) } & \multicolumn{2}{|c|}{$\begin{array}{l}\text { Mandate with Tax Credits } \\
(2022)\end{array}$} \\
\hline & $\begin{array}{l}\text { Prices } \\
(\$ / M T)\end{array}$ & $\begin{array}{l}\text { Production } \\
(\mathrm{M} \text { MT) }\end{array}$ & $\begin{array}{l}\text { Prices } \\
(\$ / M T)\end{array}$ & $\begin{array}{l}\text { Production } \\
\text { (M MT) }\end{array}$ & $\begin{array}{l}\text { Prices } \\
(\$ / M T)\end{array}$ & $\begin{array}{l}\text { Production } \\
\text { (M MT) }\end{array}$ & $\begin{array}{l}\text { Prices } \\
(\$ / M T)\end{array}$ & $\begin{array}{l}\text { Production } \\
(\mathrm{M} \text { MT) }\end{array}$ \\
\hline Corn & 127.0 & 276.7 & 117.6 & 321.5 & 145.9 & 380.0 & 111.0 & 282.2 \\
\hline Soybean & 283.4 & 81.4 & 287.0 & 89.5 & 343.6 & 82.9 & 288.0 & 92.6 \\
\hline Wheat & 213.8 & 54.7 & 212.9 & 68.5 & 228.6 & 63.3 & 219.5 & 67.9 \\
\hline Beef & 1298.1 & 16.6 & 1136.3 & 18.3 & 1230.2 & 17.8 & 1151.2 & 18.2 \\
\hline
\end{tabular}

Table 5: Regional Distribution of Cellulosic Feedstocks in 2022 (M Ha)

\begin{tabular}{|c|c|c|c|c|}
\hline & Stover & Straw & Switchgrass & Miscanthus \\
\hline \multicolumn{5}{|c|}{ Mandate } \\
\hline Midwest & & & 0.47 & 1.25 \\
\hline South & & & 0.44 & 0.79 \\
\hline Plains & 3.44 & 0.22 & 1.91 & 1.36 \\
\hline Atlantic & & & 0.21 & 1.03 \\
\hline West & & 0.79 & & \\
\hline \multicolumn{5}{|c|}{ Mandate with Subsidies } \\
\hline Midwest & 6.67 & & 0.54 & 3.08 \\
\hline South & & 0.19 & 0.67 & 1.09 \\
\hline Plains & 3.22 & 0.75 & 2.43 & 2.91 \\
\hline Atlantic & & & 0.53 & 1.63 \\
\hline West & 0.20 & 1.04 & & \\
\hline
\end{tabular}


Table 6: Effect of Biofuel Policies on Fuel Sector

\begin{tabular}{|c|c|c|c|c|}
\hline & Baseline 2007 & Baseline 2022 & Mandate & $\begin{array}{c}\text { Mandate with Tax } \\
\text { Credits }\end{array}$ \\
\hline \multicolumn{5}{|c|}{ Prices in 2022 (\$/Km or \$/Liter) } \\
\hline Vehicle Kilometers & 0.080 & 0.087 & 0.085 & 0.080 \\
\hline Corn ethanol & 0.69 & 0.66 & 0.70 & 0.54 \\
\hline Cellulosic ethanol & & & 0.70 & 0.46 \\
\hline Gasoline & 0.73 & 0.78 & 0.72 & 0.73 \\
\hline \multicolumn{5}{|c|}{ Consumption in 2022 (B Liters or B Kilometers) } \\
\hline Vehicle Kilometers & 4863.29 & 5513.13 & 5531.19 & 5595.92 \\
\hline Domestic Gasoline & 172.44 & 179.30 & 171.68 & 172.49 \\
\hline Gasoline from ROW & 354.85 & 409.24 & 349.11 & 355.26 \\
\hline Ethanol & 15.24 & 27.70 & 136.27 & 136.27 \\
\hline Corn & 13.79 & 24.82 & 53.35 & 0.00 \\
\hline Stover & & & 5.74 & 17.72 \\
\hline Straw & & & 1.02 & 1.81 \\
\hline Miscanthus & & & 47.73 & 84.79 \\
\hline Switchgrass & & & 13.01 & 17.25 \\
\hline Ethanol Imports & 1.45 & 2.88 & 3.23 & 2.24 \\
\hline Forest Residues & & & 12.19 & 12.46 \\
\hline \multicolumn{5}{|c|}{ Cumulative Consumption (Over 2007- 2022) (B Liters or B Kilometers) } \\
\hline Vehicle Kilometers & & 82885.78 & 83235.64 & 83817.33 \\
\hline Domestic Gasoline & & 2815.63 & 2747.38 & 2748.44 \\
\hline Gasoline from ROW & & 6107.17 & 5586.40 & 5589.91 \\
\hline Ethanol & & 330.78 & 1220.98 & 1316.36 \\
\hline Corn & & 295.82 & 613.22 & 131.66 \\
\hline Stover & & & 24.75 & 70.71 \\
\hline Straw & & & 2.14 & 9.36 \\
\hline Miscanthus & & & 299.76 & 674.18 \\
\hline Switchgrass & & & 107.87 & 246.22 \\
\hline Ethanol Imports & & 34.96 & 38.22 & 25.60 \\
\hline Forest Residues & & & 135.03 & 158.64 \\
\hline
\end{tabular}

Table 7: Welfare Costs of Biofuel Policies

\begin{tabular}{|l|c|c|}
\hline & $\begin{array}{c}\text { Mandate Relative } \\
\text { to BAU }\end{array}$ & $\begin{array}{c}\text { Mandate with Tax Credits } \\
\text { Relative to Mandate }\end{array}$ \\
\hline Change in Social Welfare (\$B) & 122.80 & -78.93 \\
\hline Additional Cumulative Biofuel (B Liters) & 890.21 & 95.38 \\
\hline $\begin{array}{l}\text { Benefit/ Cost per liter of additional biofuel } \\
\text { (\$/Liter) }\end{array}$ & 0.14 & -0.83 \\
\hline
\end{tabular}


Table 8: Sensitivity Analysis to Technology Parameters ${ }^{1}$

\begin{tabular}{l|c|c|c|c|c|c}
\hline & \multicolumn{2}{c}{$\begin{array}{c}\text { Rate of yield } \\
\text { increase reduced by } \\
50 \%\end{array}$} & $\begin{array}{r}\text { High cost of } \\
\text { production of } \\
\text { miscanthus }\end{array}$ & $\begin{array}{c}\text { Upper limit of 10\% } \\
\text { on energy crop } \\
\text { acres in a CRD }\end{array}$ \\
\hline & M & MS & M & MS & M & MS \\
\hline \multicolumn{7}{c}{ Land Use in 2022 (\%) } \\
\hline Total Land & 1.0 & 0.1 & 0.4 & 0.9 & -1.2 & -2.0 \\
Corn & -4.8 & -0.1 & 1.3 & -1.6 & 1.2 & 1.6 \\
Soybeans & 4.1 & -0.2 & 0.4 & -3.0 & 0.0 & -0.6 \\
Wheat & 1.7 & 0.6 & -0.9 & -1.6 & 0.8 & 1.6 \\
\hline \multicolumn{7}{|c|}{ Cellulosic Feedstock Acres in 2022 (\%) } \\
\hline Stover & 164.3 & -8.9 & 345.8 & 111.0 & 209.2 & 92.3 \\
Straw & 52.8 & -6.5 & 122.0 & 822.2 & 52.8 & 591.6 \\
Miscanthus & 31.3 & 3.6 & -100.0 & -99.0 & -20.1 & -5.7 \\
Switchgrass & 6.6 & 0.5 & 149.8 & 305.9 & -42.6 & -61.0 \\
\hline \multicolumn{7}{|c|}{ Crop Production and Prices in 2022 (\%) } \\
\hline Corn Production & -13.3 & -7.9 & 2.2 & 0.2 & 2.3 & 2.3 \\
Corn Price & 2.4 & 6.6 & 0.0 & -3.1 & 0 & 0 \\
Soybeans Production & -1.2 & -5.5 & -0.7 & -2.2 & 0 & -0.9 \\
Soybeans Price & 3.5 & 4.4 & 1.7 & 4.4 & -0.1 & 2.2 \\
Wheat Production & -6.6 & -7.6 & 0 & -1.8 & 0.7 & 0.3 \\
Wheat Price & 7.0 & 6.1 & 0 & 1.4 & 0 & -0.9 \\
\hline
\end{tabular}

Fuel Prices in 2022 and Cumulative Consumption of Fuels and Kilometers (\%)

\begin{tabular}{|c|c|c|c|c|c|c|}
\hline Gasoline Price & -0.04 & -0.01 & -0.01 & -0.3 & -0.1 & -0.3 \\
\hline Corn Ethanol price & 1.3 & 3.2 & -1.7 & -1.4 & -1.5 & -0.3 \\
\hline Cellulosic Ethanol Price & 1.5 & 0.7 & 1.8 & 16.2 & 5.7 & 16.4 \\
\hline Gasoline Consumption & -0.05 & -0.03 & -0.03 & 0.1 & -0.03 & 0.3 \\
\hline Corn Ethanol & -25.3 & -2.8 & 12.9 & -3.8 & 8.9 & 1.7 \\
\hline Cellulosic Ethanol & 27.1 & 0.6 & -14.1 & -2.8 & -9.8 & -5.9 \\
\hline Ethanol Imports & 2.0 & 0.7 & 3.0 & 7.2 & 2.7 & 9.9 \\
\hline Total Biofuels & 0 & 0.25 & 0 & -2.74 & 0 & -4.84 \\
\hline Kilometer Consumption & -0.04 & -0.01 & -0.03 & -0.1 & -0.03 & -0.1 \\
\hline \multicolumn{7}{|c|}{ Welfare Cost of Biofuels } \\
\hline Welfare Cost (\$ B) ${ }^{2}$ & \multirow[t]{3}{*}{110.2} & -69.6 & \multirow[t]{3}{*}{132.6} & -81.3 & \multirow[t]{3}{*}{133.7} & -83.2 \\
\hline Additional Biofuels (\%) & & 8.1 & & 4.9 & & 2.6 \\
\hline Welfare Cost (\$/liter) & & $\$ 0.71$ & & $\$ 1.37$ & & $\$ 2.62$ \\
\hline
\end{tabular}


Figure 1: Land Under Energy Crops

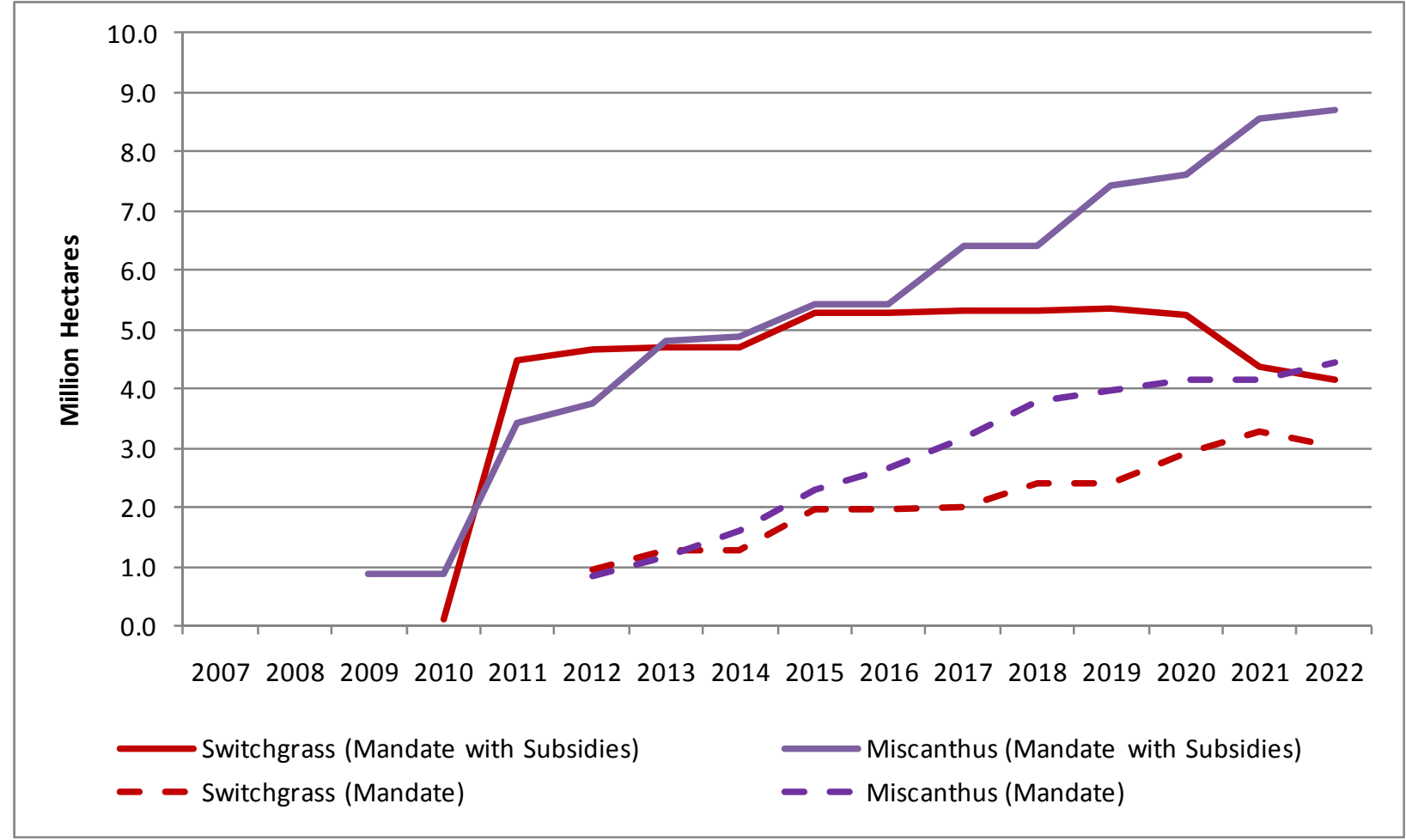




\section{References}

Abbott, P. C., C. Hurt, and W. E. Tyner. 2008. What's Driving Food Prices? Farm Foundation Issue Report, Farm Foundation, Oak Brook, IL.

Adams, D., R. Alig, B. McCarl, and B. C. Murray. 2005. FASOMGHG Conceptual Structure, and Specification: Documentation. http://agecon2.tamu.edu/people/faculty/mccarlbruce/FASOM.html.

Birur, D., T. Hertel, and W. Tyner. 2008. The Biofuels Boom: Implications for World Food Markets. Sponsored by the Dutch Ministry of Agriculture, January 9, 2008.

Bredahl, M. E., W. H. Meyers, and K. J. Collins. 1979. "The Elasticity of Foreign Demand for U.S. Agricultural Products: The Importance of the Price Transmission Elasticity." American Journal of Agricultural Economics 61 (1): 58-63.

Carley, D. H., and S. M. Fletcher. 1989. Analysis of the Impact of Alternative Government Policies on Peanut Farmers. in Experiment Station Special Publiccation 62, University of Georgia.

CBO. 2010. Using Biofuels Tax Credits to Achieve Energy and Environmental Policy Goals. Congressional Budget Office, Congress of the United States, Washington DC. .

Clifton-Brown J, C. Y-C, and H. TR. 2008. Miscanthus: Genetic Resources and Breeding Potential to Enhance Bioenergy Production. In: Genetic Improvement of Bioenergy Crops (ed.Vermerris W), pp. 273-294. Springer Science1Business Media,LLC, New York.

de Gorter, H., and D. R. Just. 2008. "The Economics of the U.S. Ethanol Import Tariff with a Blend Mandate and Tax Credit." Journal of Agricultural \& Food Industrial Organization 6: 1-21.

Dumortier, J., D. J. Hayes, M. Carriquiry, F. Dong, X. Du, A. Elobeid, J. F. Fabiosa, and S. Tokgoz. 2009. Sensitivity of Carbon Emission Estimates from Indirect Land-Use Change. Ames, Iowa, Center for Agricultural and Rural Development, Iowa State University, pp. $1-15$.

EIA. 2007. Annual Energy Outlook 2007 With Projections to 2030. U.S. Energy Information Administration. Available at http://tonto.eia.doe.gov/ftproot/forecasting/0383\%282007\%29.pdf.

EIA. 2010. Annual Energy Outlook 2010. U.S. Energy Information Administration. Available at http://www.eia.doe.gov/oiaf/aeo/.

EIA. 2010. How Dependent Are We on Foreign Oil? http://tonto.eia.doe.gov/energy_in_brief/foreign_oil_dependence.cfm.

Ellinger, P. 2008. Ethanol Plant Simulator. Urbana, Illinois, Dept. Agr Econ, University of Illinois at Urbana-Champaign.

Elobeid, A., and A. Tokgoz. 2008. "Removing Distortions in the U.S. Ethanol Market: What Does It Imply for the United States and Brazil?" American Journal of Agricultural Economics 90 (4): 918-932.

Elobeid, A. E., S. Tokgoz, D. J. Hayes, B. A. Babcock, and C. E. Hart. 2007. "the Long-Run Impact of Corn-Based Ethanol on Grain, Oilseed, and Livestock sectors with Implications for Biotech Crops." AgBioForum 10 (1): 11-18.

English, B., D. G. Ugarte, R. Menard, and T. West. 2008. Economic and Environmental Impacts of Biofuel Expansion: the Role of Cellulosic Ethanol. Atlanta, GA. 
EPA. 2010. Renewable Fuel Standard Program (RFS2) Regulatory Impact Analysis. U.S. Environmental Protection Agency, Available on line at http://www.epa.gov/otaq/fuels/renewablefuels/index.htm.

Fabiosa, J. F., J. C. Beghin, F. Dong, A. Elobeid, S. Tokgoz, and T.-H. Yu. 2009. Land Allocation Effects of the Global Ethanol Surge: Predictions from the Internationsl FAPRI Model. Ames, Iowa, Center for Agricultural and Rural Development, Iowa State University, pp. 1-21.

FAPRI. 2009. Elasticity Database.

Ferris, J., and S. Joshi 2009. Prospects for Ethanol and Biodiesel, 2008 to 2017 and Impacts on Agriculture and Food. ed. M. Khanna, J. Scheffran, and D. Zilberman, Springer.

Fortenbery, T. R., and H. Park. 2008. The Effect of Ethanol Production on the U.S. National Corn Price. Staff Paper No. 523. Department of Agricultural \& Applied Economics, University of Wisconsin-Madison.

Gao, X. M., E. J. Wailes, and G. L. Cramer. 1995. "Double-hurdle Model with Bivariate Normal Errors: An Application to U.S. Rice Demand." Journal of Agricultural and Applied Economics 27 (2): 363-376.

Graham, R. L., R. Nelson, and J. Sheehan. 2007. "Current and Potential U.S. Corn Stover Supplies." Agronomy Journal 99: 1-11.

Greene, D. L., and N. I. Tishchishyna. 2000. Costs of Oil Dependence: A 2000 Update.

Gunderson, A. C., E. B. Davis, and I. H. Jager. 2008. Exploring Potential U.S.Switchgrass Production for Lignocellulosic Ethanol. ORNL/TM-2007/183. Oak Ridge, TN: Oak Ridge National Laboratory.

Hayes, D., B. Babcock, J. Fabiosa, S. Tokgoz, A. Elobeid, and T.-H. Yu. 2009. "Biofuels: Potential Production Capacity, Effects on Grain and Livestock Sectors, and Implications for Food Prices and Consumers." Journal of Agricultural and Applied Economics 41 (2): $1-27$.

Heaton, E., F. Dohleman, and S. Long. 2008. "Meeting US Biofuel Goals with Less Land: the Potential of Miscanthus." Global Change Biology 14: 2000-2014.

Heaton, E. A., F. G. Dohleman, and S. P. Long. 2008. "Meeting US biofuel goals with less land: the potential of Micanthus." Global Change Biology 14: 2000-2014.

Hertel, T. W., W. E. Tyner, and D. K. Birur. 2010. "The Global Impacts of Biofuel Mandates." The Energy Journal 31 (1): 75-100.

Hertel, W. T., W. E. Tyner, and D. K. Birur. 2008. Biofuels for all? Understanding the Global Impacts of Multinational Mandates. GTAP Working Paper No.51.

Hettinga, W. G., H. M. Junginger, S. C. Dekker, M. Hoogwijk, A. J. McAloon, and K. B. Hicks. 2009. "Understanding the Reductions in US Corn Ethanol Production Costs: An Experience Curve Approach." Energy Journal 37: 190-203.

Huang, H., and M. Khanna. 2010. An Econometric Analysis of U.S. Crop Yields and Cropland Acreages: Implications for the Impact of Climate Change. Paper presented at AAEA annual meeting, Denver, Colorado, 25-27July (http://ageconsearch.umn.edu/handle/61527).

Jain, A., M. Khanna, M. Erickson, and H. Huang. 2010. "An Integrated Biogeochemical and Economic Analysis of Bioenergy Crops in the Midwestern United States." GCB Bioenergy: In Press.

Lemus, R., and D. L. Parrish. 2009. "Herbaceous Crops with Potential for Biofuel Production in the USA." CABI Reviews: Perspectives in Agriculture, Veterinary Science, Nutrition and Natural Resources 4: 1-23. 
Lewandowski, I., J. M. O. Scurlock, E. Lindvall, and M. Christou. 2003. "The Development and Current Status of Perennial Rhizomatous Grasses as Energy Crops in the US and Europe." Biomass and Bioenergy 25 (4): 335-361.

Lewandowski, I., J. M. O. Scurlock, E. Lindvall, and M. Christou. 2003. "The development and current status of potential rhizomatous grasses as energy crops in the US and Europe." Biomass and Bioenergy 25 (4): 335-361.

Malcolm, S. 2008. Weaning Off Corn: Crop Residues and the Transition to Cellulosic Ethanol. St. Louis, MO.

McCarl, B. A., and U. A. Schneider. 2001. "Greenhouse Gas Mitigation in U.S. Agriculture and Forestry." Science 294: 2481-2482.

McCarl, B. A., and T. H. Spreen. 1980. "Price Endogenous Mathematical Programming as a Tool for Policy Analysis." American Journal of Agricultural Economics 62: 87-102.

McPhail, L. L., and B. A. Babcock. 2008. Short-Run Price and Welfare Impacts of Federal Ethanol Policies. 08-WP 468,Center for Agricultural and Rural Development, Iowa State University.

Metcalf, G. E. 2008. "Using Tax Expenditures to Achieve Energy Policy Goals." American Economic Review: Papers \& Proceedings 98 (2): 90-94.

NRC. 2002. Effectiveness and Impact of Corporate Average Fuel Economy (CAFE) Standards. National Research Council.

Önal, H., and B. A. McCarl. 1991. "Exact Aggregation in Mathematical Programming Sector Models." Canadian Journal of Agricultural Economics 39: 319-334.

Pfuderer, S., G. Davies, and I. Mitchell. 2010. The Role of Demand for Biofuel in the Agricultural Commodity Price Spikes of 2007/2008. Food and Farming Analysis, Defra.

Piggott, N. E., and M. K. Wohlgenant. 2002. "Price Elasticities, Joint Products, and International Trade." Australian Journal of Agricultural and Resource Economics 46 (4): 487-500.

Reilly, J., A. Gurgel, and S. Paltsev. 2009. Biofuels and Land Use Change. ed. M. Khanna St. Louis, MO, Farm Foundation.

Semere, T., and F. M. Slater. 2007. "Invertebrate Populations in Miscanthus (Miscanthus×giganteus) and Reed Canary-Grass (Phalaris Arundinacea) Fields." Biomass and Bioenergy 31 (1): 30-39.

Sheehan, J., A. Aden, K. Paustian, K. Killian, J. Brenner, M. Walsh, and R. Nelson. 2003. "Energy and Environmental Aspects of Using Corn Stover for Fuel Ethanol." Journal of Industrial Ecology 7: 117-146.

Takayama, T., and G. G. Judge. 1971. Spatial and Temporal Price and Allocation Models. Amsterdam: North Holland Publ. Co.

Tokgoz, S., A. Elobeid, J. F. Fabiosa, D. Hayes, B. A. Babcock, T.-H. Yu, F. Dong, C. E. Hart, and J. C. Beghin. 2007. Emerging Biofuels: Outlook of Effects on U.S. Grain, Oilseed, and Livestock Markets.

Tyner, W., and F. Taheripour. 2008. "Policy Options for Integrated Energy and Agricultural Markets." Review of Agricultural Economics 30 (3): 387-396.

Ugarte, D. d. l. T., B. C. English, C. Hellwinckel, T. O. West, K. L. Jensen, C. D. Clark, and R. J. Menard. 2009. Analysis of the Implications of Climate Change and Energy Legislation to the Agricultural Sector. Knoxville, Tennessee., Department of Agricultural Economics, Institute of Agriculture, The University of Tennessee.

Ugarte, D. G., M. E. Walsh, H. Shapouri, and S. P. Slinsky. 2003. The Economic Impacts of Bioenergy Crop Production on U.S. Agriculture. U.S. Department of Agriculture.

USDA. 2010. Available at: http://www.nass.usda.gov/. 
USDA/ERS. 1997. General Crop Management Practices. Available at: http://www.ers.usda.gov/publications/sb969/sb969e.pdf.

USDA/ERS. 2009. Commodity and Food Elasticities: Demand Elasticities from Literature.

Available at: http://www.ers.usda.gov/Data/Elasticities/query.aspx

USDA/ERS. 2010. Available at: http://www.ers.usda.gov/.

USDA/NASS. 2009. Available at: http://quickstats.nass.usda.gov/.

USDA/NASS. 2009. U.S. \& All States County Data - Crops. Available at: http://www.nass.usda.gov/.

van den Wall Bake, J. D., M. Junginger, A. Faaij, T. Poot, and A. Walter. 2009. "Explaining the Experience Curve: Cost Reductions of Brazilian Ethanol from Sugarcane." Biomass and Bioenergy 33 (4): 644-658.

Wallace, R., K. Ibsen, A. McAloon, and W. Yee. 2005. Feasibility Study for Co-Locating and Integrating Ethanol Production Plants from Corn Starch and Lignocellulogic Feedstocks.

Wilcke, W., and G. Wyatt. 2002. Grain Storage Tips. Twin Cities, MN, The University of Minnesota Extension Service, the University of Minnesota.

Wortmann, C. S., R. N. Klein, W. W. Wilhelm, and C. Shapiro. 2008. Harvesting Crop Residues. University of Nebraska

Wullschlegera, S. D., E. B. Davisb, M. E. Borsukb, C. A. Gundersona, and L. R. Lyndb. 2010. "Biomass Production in Switchgrass across the United States: Database Description and Determinants of Yield " Agronomy Journal 102 (4): 1158-1168. 